\title{
22. FORAMINIFERS FROM DEEP SEA DRILLING PROJECT SITES 434, 435, AND 436, JAPAN TRENCH
}

\author{
Peter R. Thompson, Lamont-Doherty Geological Observatory of Columbia University, Palisades, New York
}

\begin{abstract}
Sediments containing foraminifers were penetrated at all three sites drilled during DSDP Leg 56 as the first part of a Japan Trench transect. Two sites were on the inner wall of the trench (Site 435, $3401 \mathrm{~m}$; Site $434,5986 \mathrm{~m}$ ), and one was on the oceanic plate east of the trench (Site 436, $5240 \mathrm{~m}$ ). Because the lysocline in this area is at about 2000 meters and the calcite-compensation depth is at about 3500 meters, calcareous foraminifers are generally not abundant in the sediments; however, the biostratigraphy based upon planktonic foraminifer faunas agrees with that based predominantly upon siliceous microfossils from the sites. Hole 435A yielded the oldest of the planktonic foraminifers from the three sites.

Two plankonic foraminifer lineages were particularly important in determining the biostratigraphy of the sites. The Neogloboquadrina asanoi-kagaensis-himiensis-eggeri lineage underwent rapid evolution around the Pliocene-Pleistocene boundary and is widely recognized in the oil-producing region of northern Japan and in the northwest Pacific. Second, the Globorotalia orientalis-inflata praeinflata-inflata inflata lineage evolved during the Pliocene; tests of these species are very resistant to dissolution. During the Pleistocene, individuals of Neogloboquadrina pachyderma preferentially coiled sinistrally in the cold waters north of the subarctic boundary and dextrally in temperate waters south of it. The ratio of these two forms was used to identify relative motions of near-surface waters of the Kuroshio and Oyashio Currents in the transect area in response to Quaternary climatic fluctuations.

Benthic foraminifers characteristic of modern surface sediments were used to interpret uplift and plate motions of the Japan Trench as recorded at Leg 56 sites. Materials from the DSDP sites and from piston cores taken elsewhere in the region permitted extension of the foraminifer bathymetry of Matoba (1977) to the bottom of the Japan Trench; the lower bathyal, abyssal, and hadal biofacies are recognized. The sediments of the oceanic plate have a benthic foraminifer fauna distincly different from that of the inner trench wall at comparable depths. There is no evidence from these contrasting faunas to indicate that sediments of the oceanic plate are added to the landward trench wall during subduction.

Manganese micronodules recovered from pelagic clay at Site 436 contained external models of Paleogene(?) juvenile planktonic foraminifers. That the tests of these foraminifers did not dissolve before the manganese was deposited is significant to theories of manganesenodule formation.

Two new foraminifer species, Globorotalia wilesi and Silicosigmoilina splendida, are named.
\end{abstract}

\section{INTRODUCTION}

The DSDP transect across the Japan Trench (Legs 56 and 57) was designed to sample representative sections of contrasting elements of this tectonically active margin, including the oceanic plate (Sites 436 and 437), the base of the landward trench wall (Sites 434 and 441), the mid-slope terrace (Sites 435 and 440), and the inner trench slope (Sites 438 and 439). We suspected that, in accord with observations at other trenches, sediments of the oceanic plate were being scraped off during subduction, forming an accretionary wedge at the foot of the landward wall. Foraminifer studies were intended to provide (1) planktonic foraminifer ages to determine accumulation rates and to identify stratigraphic gaps within the sections, and (2) benthic foraminifer data 
which would help us interpret bathymetric history and identify sediments displaced downslope on the landward trench wall or scraped from the oceanic plate.

This report deals with the foraminifers from Sites 434,435 and 436, inclement weather prevented coring at Site 437; foraminifers of Sites 438-441 (Leg 57) are treated by Keller (this volume). Figure 1 shows Leg 56 sites and sites of piston cores from which supplementary material was obtained. Table 1 lists coring-site locations and corresponding water depths. These cores were taken slightly north of the confluence of the warm, northward-flowing Kuroshio Current and the cold, southward-flowing Oyashio Current. Tully (1964) reported that the position of this confluence is highly variable and depends upon the relative seasonal strength of the two currents. The presence of one or the other of these currents offshore directly affects the climate of the Pacific coast of Japan today, and numerous studies have suggested profound climatic fluctuations since the middle Miocene.

\section{METHODS AND MATERIALS}

All samples (one $10-\mathrm{cm}^{3}$ sample per section were initially processed aboard the Glomar Challenger immediately after the cores were opened. At that time, the interstitial moisture of the sediments allowed washing with tap water alone, although several samples later were cleaned more thoroughly with hydrogen peroxide and Calgon. I wet-sieved the samples on a $44 \mu \mathrm{m}$ screen and dried the residues in an oven at $100^{\circ} \mathrm{C}$. In a few instances, trichloroethylene was employed for heavyliquid separation of the foraminifers from heavy minerals. The samples were dry-seived at the time of ex-

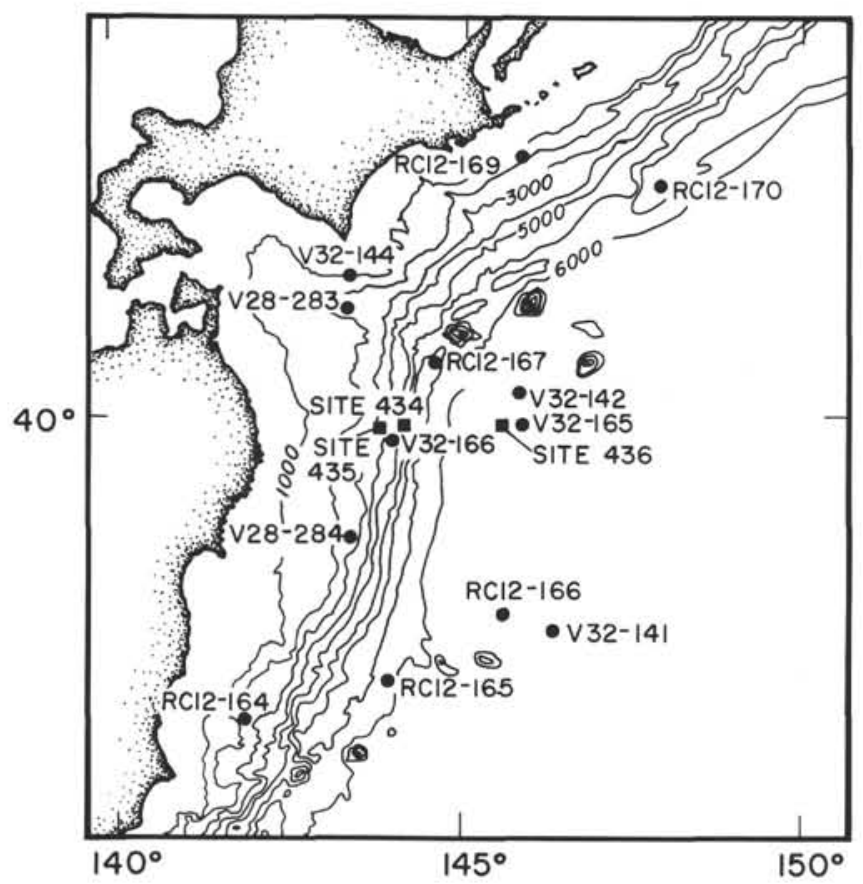

Figure 1. Locations of DSDP Leg 56 sites and cores from Lamont-Doherty Geological Observatory collection. Bathymetric contours in meters.
TABLE 1

Locations of Coring Sites near the Japan Trench

\begin{tabular}{lllc}
\hline Core Site & Latitude & Longitude & $\begin{array}{c}\text { Water Depth } \\
(\mathrm{m})\end{array}$ \\
\hline Site 434 & $39^{\circ} 44.76^{\prime} \mathrm{N}$ & $144^{\circ} 06.12^{\prime} \mathrm{E}$ & 5986 \\
Site 435 & $39^{\circ} 44.09^{\prime} \mathrm{N}$ & $143^{\circ} 47.53^{\prime} \mathrm{E}$ & 3401 \\
Site 436 & $39^{\circ} 56.96^{\prime} \mathrm{N}$ & $145^{\circ} 33.47^{\prime} \mathrm{E}$ & 5240 \\
RC12-164 & $36^{\circ} 27^{\prime} \mathrm{N}$ & $141^{\circ} 53^{\prime} \mathrm{E}$ & 2319 \\
RC12-165 & $37^{\circ} 05^{\prime} \mathrm{N}$ & $143^{\circ} 51^{\prime} \mathrm{E}$ & 6485 \\
RC12-166 & $38^{\circ} 49^{\prime} \mathrm{N}$ & $145^{\circ} 45^{\prime} \mathrm{E}$ & 5243 \\
RC12-167 & $40^{\circ} 45^{\prime} \mathrm{N}$ & $144^{\circ} 37^{\prime} \mathrm{E}$ & 7425 \\
RC12-169 & $43^{\circ} 00^{\prime} \mathrm{N}$ & $146^{\circ} 04^{\prime} \mathrm{E}$ & 1845 \\
RC12-170 & $42^{\circ} 39^{\prime} \mathrm{N}$ & $148^{\circ} 12^{\prime} \mathrm{E}$ & 7240 \\
V 28-283 & $41^{\circ} 15^{\prime} \mathrm{N}$ & $143^{\circ} 09^{\prime} \mathrm{E}$ & 2158 \\
V 28-284 & $38^{\circ} 33^{\prime} \mathrm{N}$ & $143^{\circ} 34^{\prime} \mathrm{E}$ & 2803 \\
V 32-141 & $37^{\circ} 50^{\prime} \mathrm{N}$ & $146^{\circ} 54^{\prime} \mathrm{E}$ & 5359 \\
V 32-142 & $40^{\circ} 23.5^{\prime} \mathrm{N}$ & $145^{\circ} 53^{\prime} \mathrm{E}$ & 5169 \\
V 32-144 & $41^{\circ} 33^{\prime} \mathrm{N}$ & $143^{\circ} 19^{\prime} \mathrm{E}$ & 1054 \\
V 32-165 & $39^{\circ} 54^{\prime} \mathrm{N}$ & $145^{\circ} 56^{\prime} \mathrm{E}$ & 5174 \\
V 32-166 & $39^{\circ} 28^{\prime} \mathrm{N}$ & $144^{\circ} 00^{\prime} \mathrm{E}$ & 4673 \\
\hline
\end{tabular}

amination, and all specimens greater than $149 \mu$ were counted.

In order to better interpret benthic foraminifer faunas, the tops of several piston cores in the LamontDoherty Geological Observatory core collection from the same region have been processed and picked also.

Important taxa are illustrated in Plates 1 through 9.

\section{BIOSTRATIGRAPHY OF PLANKTONIC FORAMINIFERS}

Latitudinal faunal gradients in the North Pacific brought about by climatic deteriorations since the middle Miocene have created biostratigraphic problems. Ecological restrictions have produced distinct bioprovinces that make correlation using the standard (equatorial) zonal scheme of Blow (1969) difficult. For example, Blow's zone N. 20 (Globorotalia multicamerata-Pulleniatina obliquiloculata Partial Range Zone) cannot be recognized at temperate or higher latitudes, because the two characteristic tropical species are absent (see Vincent, 1975; Keller, 1978). As a result, Shinbo and Maiya (1971), dealing with the oil-producing areas of northern Japan, proposed a set of foraminifer zones for regional correlations. Many of the taxa used by Shinbo and Maiya are found also in cores from the northwest Pacific (Maiya et al., 1976). Many of these taxa have been used in this paper (Figures 2 and 3).

Ikebe et al. $(1972,1977)$ correlated the Neogene marine sections of Japan and recognized that the assortments of datum levels and zones of southwestern Japan are intergradational with those in northern Japan based on different species (see Figure 2).

Western Pacific planktonic foraminifer datum levels and changes in coiling direction (Pulleniatina and NeOgloboquadrina pachyderma) from late Pliocene to Holocene have been identified precisely in paleomagnetically dated Lamont-Doherty piston cores ranging from equatorial through temperate to northern subpolar latitudes (Figure 3; Thompson, 1976, 1977, 1978). Many of the events are widely recognized in the North Pacific 


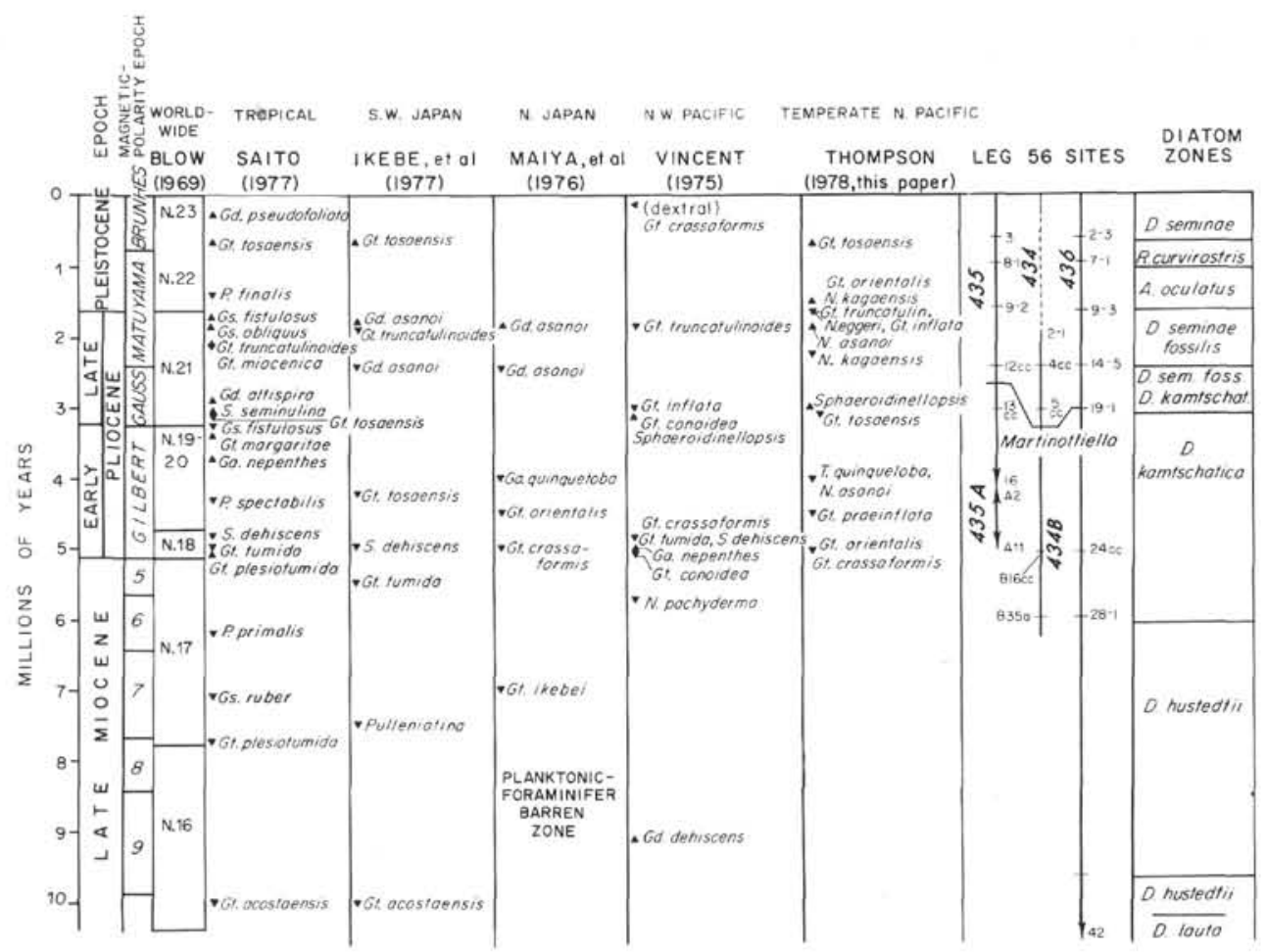

Figure 2. Biostratigraphic zonations and datum levels of the Pacific compared with Leg 56 planktonic foraminifer datum levels. Upward-pointing triangles denote extinctions; downward-pointing triangles denote appearances; sideways-pointing triangles mark coiling changes. Abbreaviations for genera: $G a$ Globigerina, $G d$ Globoquadrina, Gs Globigerinoides, Gt Globorotalia, $N$ Neogloboquadrina, $P$ Pulleniatina, $S$ Sphaeroidinella, $T$ Turborotalita. Location (core-section) of diatom-zone boundaries (Harper, this volume, after Koizumi, 1975) are marked on the Leg 56 cores, along with the top datum of Martinottiella. The correlation of datum levels and zones with the paleomagnetic time scale is after Ryan et al. (1974).

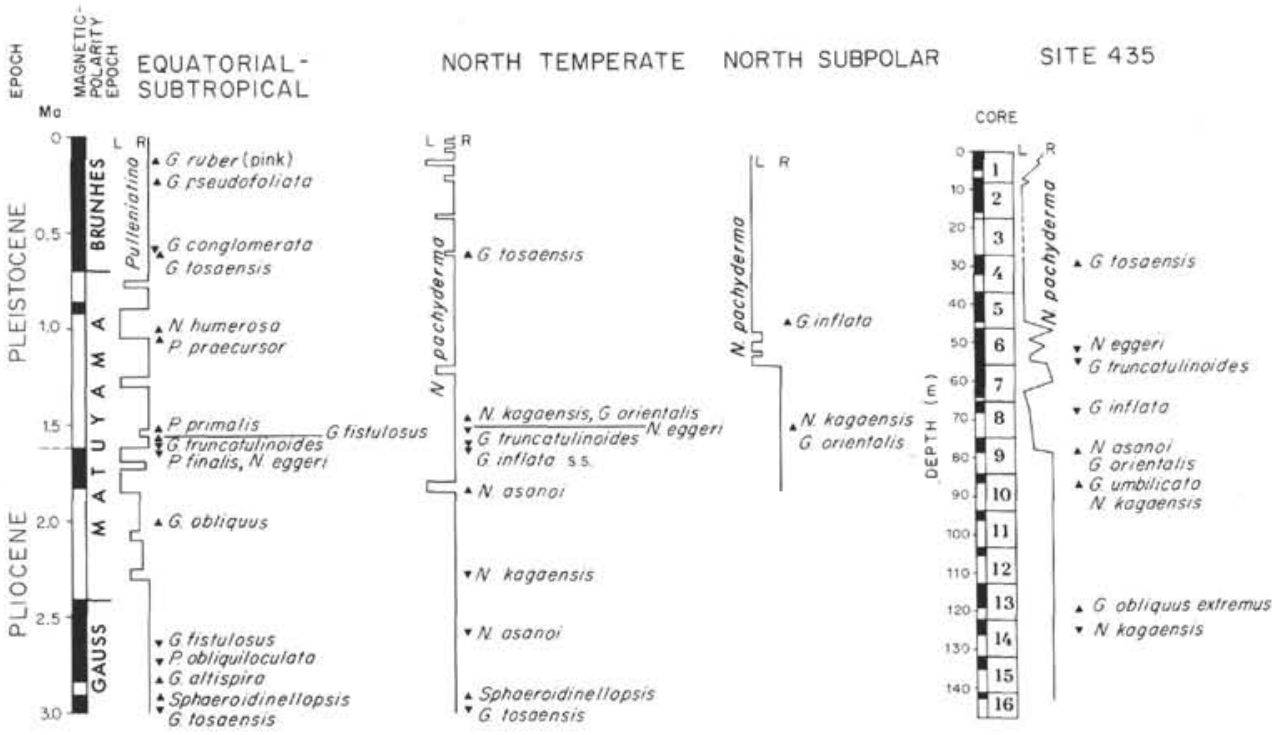

Figure 3. Planktonic-foraminifer biostratigraphy for western-Pacific piston cores compared with Site 435. Coiling of Pulleniatina and $\mathrm{N}$. pachyderma have been generalized. 
because of the intense circulation of the Kuroshio Current, which has introduced tropical forms to temperate regions. In late-Cenozoic sediments, the Globorotalia tosaensis extinction datum $(0.59 \mathrm{Ma})$ and the G. truncatulinoides appearance datum $(\sim 1.65 \mathrm{Ma})$ (Thompson and Sciarrillo, 1978), as well as the Sphaeroidinellopsis extinction datum (3.0 Ma), are widely recognized.

The coiling-direction history of $N$. pachyderma is different on either side of the subarctic boundary (defined by the northern edge of the Kuroshio Current east of Japan).

North of the front, populations of $N$. pachyderma coiled dextrally before 1.0 to $1.2 \mathrm{Ma}$, when they were succeeded by sinistrally coiling populations which have persisted to the present (Kent et al., 1971). A similar pattern was observed in the oil-producing provinces of northern Japan by Maiya et al., (1976), who interpreted the shift as showing the onset of mid-latitude climatic fluctuations in the northern hemisphere.

South of the subarctic boundary, the coiling direction of $N$. pachyderma has been predominantly dextral since the early Pliocene, except during times of southward displacement of the subarctic boundary (Thompson and Shackleton, 1979). During the last 3 m.y., among populations of the north temperate region, there have been eight major shifts toward sinistral coiling, six within the Brunhes magnetic-polarity epoch (Figure 3). Those in the Brunhes coincide with oxygen-isotope stages 2, 4, 6, 8, 12, and 16 of Shackleton and Opdyke (1973); no coiling-direction change has been identified with stages 10 and 14 .

Cores from DSDP Site 435, near the KuroshioOyashio confluence, and also above the carbonate-compensation depth, show a $N$. pachyderma coiling-direction history which reflects an alternation of warm and cold waters in the area through time. In the Pliocene, populations of $N$. pachyderma are dextral (Figure 3 ). Near the base of the Pleistocene, there is a shift to increasing numbers of sinistral forms, although the total number of individuals is small and preservation is poor. Cores 435-5 and 435-6 show the influence of cold waters at this site, and very large numbers of sinistral forms continue upward through Core 435-2. Specimens from Core 435-1 are evenly divided between sinistral and dextral, suggesting a lessening of cold-water influence since the last glacial age.

In the northwest Pacific, the Pliocene-Pleistocene boundary can be identified with the useful but apparently local lineage Neogloboquadrina asanoi-N. kagaensis- $N$. himiensis- $N$. eggeri. Maiya et al. (1976) placed these four species in Globoquadrina, on the basis of the large, robust test and occasional toothlike umbilical flap. Bandy et al. (1967) erected the genus Neogloboquadrina for tropical and subtropical members of this morphological group which had evolved from a globorotaliid ancestor rather than a globoquadrinid. Sediments from the northwest-Pacific region which should bear the unknown ancestor to the species asanoi are typically barren of planktonic foraminifers. My ex- amination of scanning electron micrographs of the surface ultrastructures of these forms disclosed that the asanoi group had a cortical thickening and pore-pit structure similar to that found in tropical Neogloboquadrina, as in $N$. humerosa and $N$. dutertrei $(=N$. eggeri of many authors). On this basis I have placed the northwest-Pacific asanoi lineage into Neogloboquadrina.

Two main evolutionary trends occur in the $N$. asanoi lineage. First, there is a gradual increase in the number of chambers in the final whorl, from four in N. asanoi to five or six in $N$. eggeri. The additional chambers permit a second change, a modification of the equatorial profile from subrhomboidal to subquadrate and finally subcircular in late phylogenetic stages (Maiya et al., 1976). Many individuals show a distinct protrusion of the early whorls above later ones on the spiral side (Plate 3, Figure 9b).

An unresolved problem in the taxonomy of this group centers about $N$. eggeri: it developed from the $N$. asanoi lineage in the northwest Pacific (Maiya et al., 1976 ) at the same time the same morphotype (called $N$. dutertrei dutertrei Group A) developed in subtropical latitudes from the $N$. acostaensis-humerosa lineage (Srinivasan and Kennett, 1976).

In northwest-Pacific sediments, the extinction of $N$. asanoi is associated with the early Olduvai magneticpolarity event (Matuyama epoch), and also with a major peak of sinistral coiling in $N$. pachyderma (Figure 3 ). The extinctions of $N$. kagaensis and $N$. himiensis, as well as the first appearance of $N$. eggeri, are poorly resolved because of dissolution and bioturbation in deep-sea piston core RC10-161 from the Shatsky Rise (Maiya et al., 1976; Thompson, unpublished data). These events, however, are closely associated with the first appearance of $G$. truncatulinoides near the Pliocene-Pleistocene boundary.

DSDP Site 435 has a higher sedimentation rate than RC10-161, which, in principle, should permit better separation of sequential biostratigraphic events. The highest occurrence of $N$. asanoi is in Section 435-6-3, the first occurrence of $G$. truncatulinoides in Section 435-6, CC, and the first $N$. eggeri in Section 435-6-3 also (Table 2). Forms referrable to $N$. kagaensis or $N$. himiensis are so sporadic in Cores 435-9 to 435-14 that no reliance is placed on their ranges. The "top" occurrence of $N$. asanoi in Cores 435-8 and 435-9 is in agreement with the placement of the Pliocene-Pleistocene boundary in Section 435-9-2 on the basis of diatoms. Use of $G$. truncatulinoides and $N$. eggeri causes conflict by placing the boundary in Core 435-6. Populations of sinistrally coiled $N$. pachyderma in this interval mark the invasion of subarctic waters into this area. This event is recorded in other deep-sea sediment sections in association with the early Olduvai magnetic-polarity events. By the time this cold pulse subsided (Cores 435-6 and 435-7), G. truncatulinoides had already evolved elsewhere. The next sinistral-coiling peak of $N$. pachyderma in the lower part of Core 435-6 is correlated with peak $C$ of 
TABLE 2

Planktonic Foraminifers at DSDP Site 435

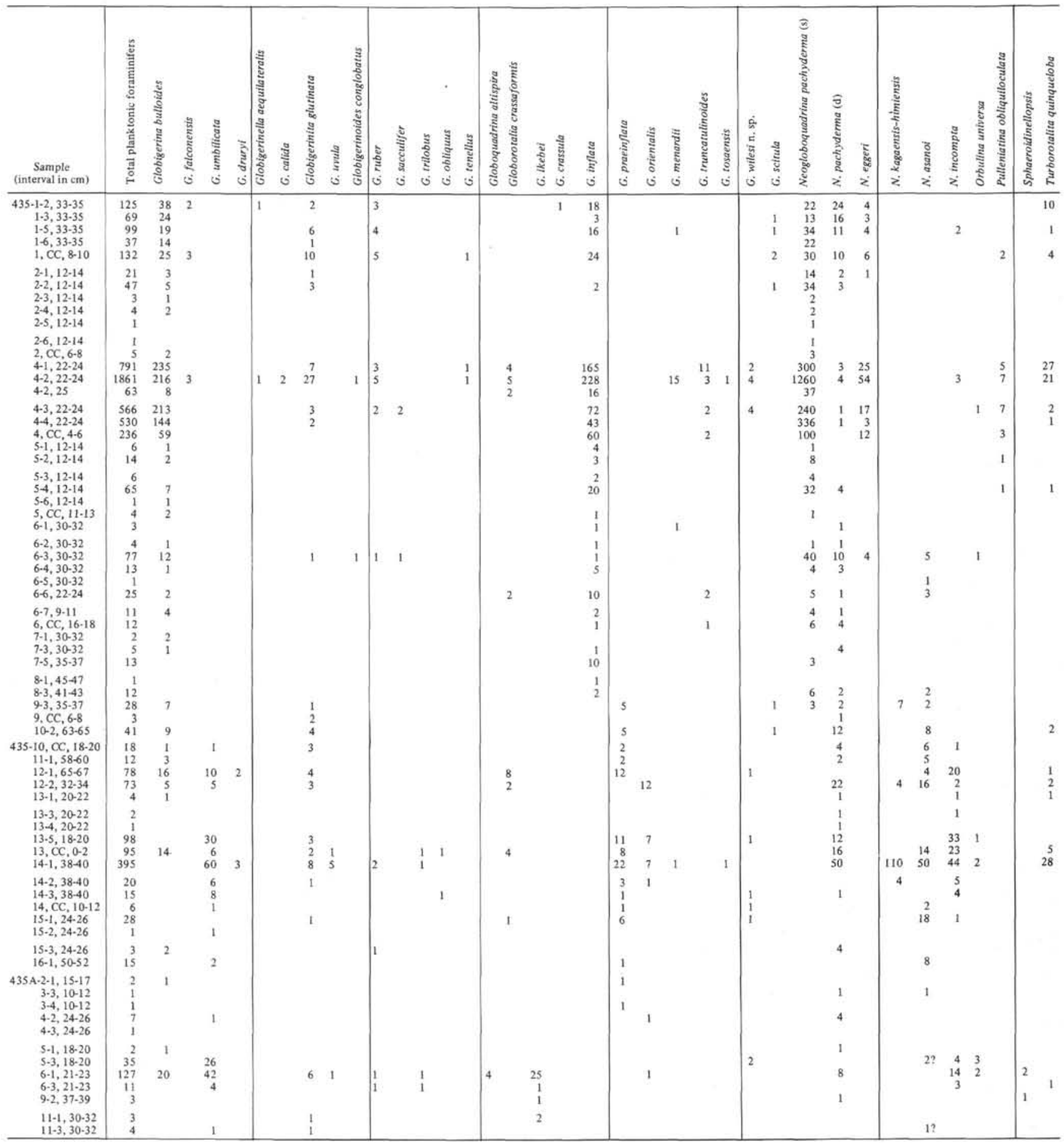

Maiya et al. (1976), dated at 1.0 to 1.2 Ma. At this time, the occurrence of $N$. asanoi in Core 435-6 is relegated to reworking.

Vincent (1975) found the Globorotalia miozea-G. conoidea-G. conomiozea-G. sphericomiozea-G. puncticulata-G. inflata lineage to be useful biostratigraphically in Pliocene temperate-latitude sediments east of the present area. However, as had happened with the $N$. asanoi lineage just discussed, a local lineage terminating with $G$. inflata can be found in the vicinity of the northern-Japan oil-producing region. Maiya et al. (1976) gave this lineage as $G$. orientalis-G. inflata praeinflata- $G$. inflata inflata. They proposed $G$. adamentea Saito as a possible ancestral form, but this middle- 
Miocene form and the intervening phylogenetic events have been lost in the "planktonic foraminifer barren zone" of the record (Figure 2).

In samples from the lower part of Hole 435A (Plate 5 , Figures 6-11; Table 2), and particularly in Core $435 \mathrm{~A}-6$, I found specimens I consider to be morphologically intermediate between those figured by Vincent (1975, pl. 2, figs. 9-21) as G. sphericomiozea and G. conoidea. They also resemble G. suterae of Echols (1973, pl. 1, figs. 12?, 13, not 14). The specimens from Hole $435 \mathrm{~A}$ are slightly elliptical in equatorial profile, like $G$. conoidea, but lack the imperforate carina; there are usually five chambers in the final whorl, as in $G$. suterae, but the umbilical side is less inflated. In this respect, they are close to G. puncticulata of Deshayes (fide Ellis and Messina, 1940 et seq.) prior to the designation of a lectotype by Banner and Blow (1960). Maiya et al. (1976) and Maiya (pers. comm.) have proposed $G$. ikebei for individuals morphologically like those from Hole 435A. Regardless of the specific name we attach to these very similar morphotypes, they are restricted to the early Pliocene over much of the North Pacific, making them important guide fossils worthy of more careful study.

Biostratigraphic events before the late Pliocene are difficult to recognize in my transect sites because of the poor preservation of planktonic foraminifers. I have used the datum levels of Maiya (1975) to characterize this interval (Figure 2), and the resolution for Hole $435 \mathrm{~A}$ is limited to those specimens recovered (Table 2). Without accompanying last appearances, it seems unwise to allow only the rare occurrences of taxa used for first-appearance datum levels to define the biostratigraphy at the base of the hole. If the extinction of $G$. nepenthes can be used to identify the Miocene-Pliocene boundary in this area, as it has been used elsewhere in the North Pacific (Figure 2), Hole 435A did not reach the Miocene.

\section{FORAMINIFER BATHYMETRY}

Benthic foraminifers constitute the vast majority of specimens I picked from the Leg 56 samples. The downcore faunal variations by themselves ranged from inconclusive to contradictory, but, when combined with the present-day biogeographic distributions determined from my supplementary data (Figures 1, 4, and 5), these variations show a complicated, although reasonable, history of uplift and down-slope slumping.

The modern planktonic foraminifer lysocline (Parker and Berger, 1971) lies at about 2000 meters in the area of the Japan Trench (based on the preservation of planktonic species in all samples examined from the core-top data). The carbonate-compensation depth (CCD) lies at about 3500 meters. Between the lysocline and the $\mathrm{CCD}$, only rare individuals of dissolutionresistant planktonic species such as $G$. inflata and thickwalled $G$. bulloides can be found. Calcareous benthonic foraminifers are very abundant down to the CCD and are common below it. Below the CCD, agglutinated benthic species dominate foraminifer faunas.
The foraminifer bathymetry zonation of Matoba (1977) for the shelf and slope off Sendai, Japan, has been adopted and expanded here to the bottom of the Japan Trench (Figures 4 and 5). Biogeographic data from the piston cores permit the recognition of lower bathyal, abyssal, and hadal benthic foraminifer biofacies. My present coverage has not been wide enough to identify lateral biofacies variations which might be expected in the region flanking the confluence of the Kuroshio and Oyashio Currents. Kitazato (1977) has been able to delineate general regional changes in the sublittoral and upper bathyal biofacies along the Pacific coast of Japan. The majority of the samples studied here were recovered from depths below these levels and are largely beneath the influences of the near-surface ocean currents.

The lower bathyal benthic-foraminifer biofacies is subdivided into two zones. The upper is the Elphidium batialis-Bulimina aculeata Zone (1800-2700 m) of Matoba (1977), which is very rich in the two named species and has also Nonionellina labradorica, Uvigerina akitaensis, Islandiella helenae, Globocassidulina rossensis, and Stainforthia loeblichi. The occurrence of Elphidium (unkeeled) at these depths is noteworthy, since this genus is a classical indicator of shallow water. The form appears to be autochthonous, because it is very abundant and well preserved, and, more important, because other shallow-water forms which might indicate downslope displacements are absent. Saidova (1966) has reported that the water temperature is $3^{\circ} \mathrm{C}$ at this level, and that the oxygen content is $1.5 \mathrm{ml} /$ liter.

The lower is the Uvigerina senticosa-Melonis pompilioides Zone (2700-3300 m), characterized by the two named species and by Pullenia bulloides, Eggerella bradyi, $N$. labradorica, and rare E. batialis. The lower limit of this zone approaches the CCD $(3500 \mathrm{~m})$, and the abundances of the calcareous taxa decrease sharply. At the same time, the relative frequencies of agglutinated forms less reliant on calcium carbonate gradually increase. Absolute abundances of benthic foraminifers are greatly reduced in comparison to those of the upper zone. According to Saidova (1966), the water temperature at this level is $2^{\circ} \mathrm{C}$, and the oxygen content is 1.5 to $2.0 \mathrm{ml} /$ liter.

The abyssal region is subdivided into two benthicforaminifer biofacies. The first is the Saccammina sphaerica Zone (3300-6000 m), which contains the named species and Eggerella bradyi. Down-core associations at my Leg 56 sites suggest that Martinottiella communis also inhabited this biofacies in the past. Water temperatures are below $2^{\circ} \mathrm{C}$ (Saidova, 1966).

The sediments of the oceanic plate between 5000 and $6000 \mathrm{~m}$ are placed in the Reophax-Recurvoides Zone. The new species Silicosigmoilina splendida is commonly present. Faunal abundances are typically low.

The hadal region below 6000 meters is characterized by agglutinated taxa only (Belyaev, 1966), some of which are eurybathyal. Reophax is the only genus present in the samples I examined, so this zone is called the Reophax Zone. Absolute abundances are very low, but 


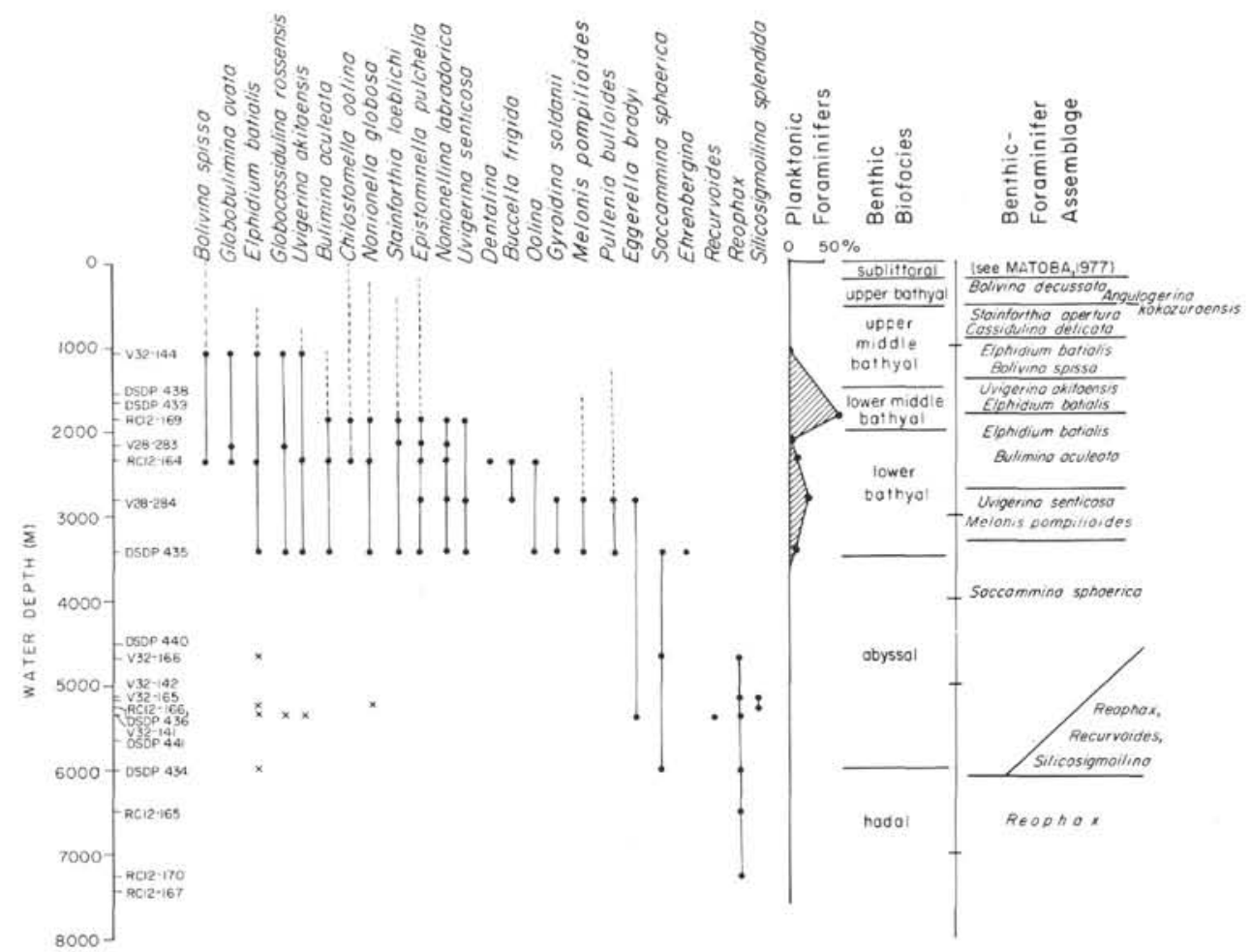

Figure 4. Bathymetric distribution of dominant benthic foraminifer taxa at DSDP Leg 56 sites and LDGO piston-core sites in the Japan Trench area. Assemblages shallower than 2500 meters are from Matoba (1977). Division of abyssal biofacies recognizes separate landward (left) and seaward (right) assemblages on either side of the trench. Small crosses denote specimens considered to be displaced by recent slumping; dashed lines mark ranges noted by workers using samples I have not examined.

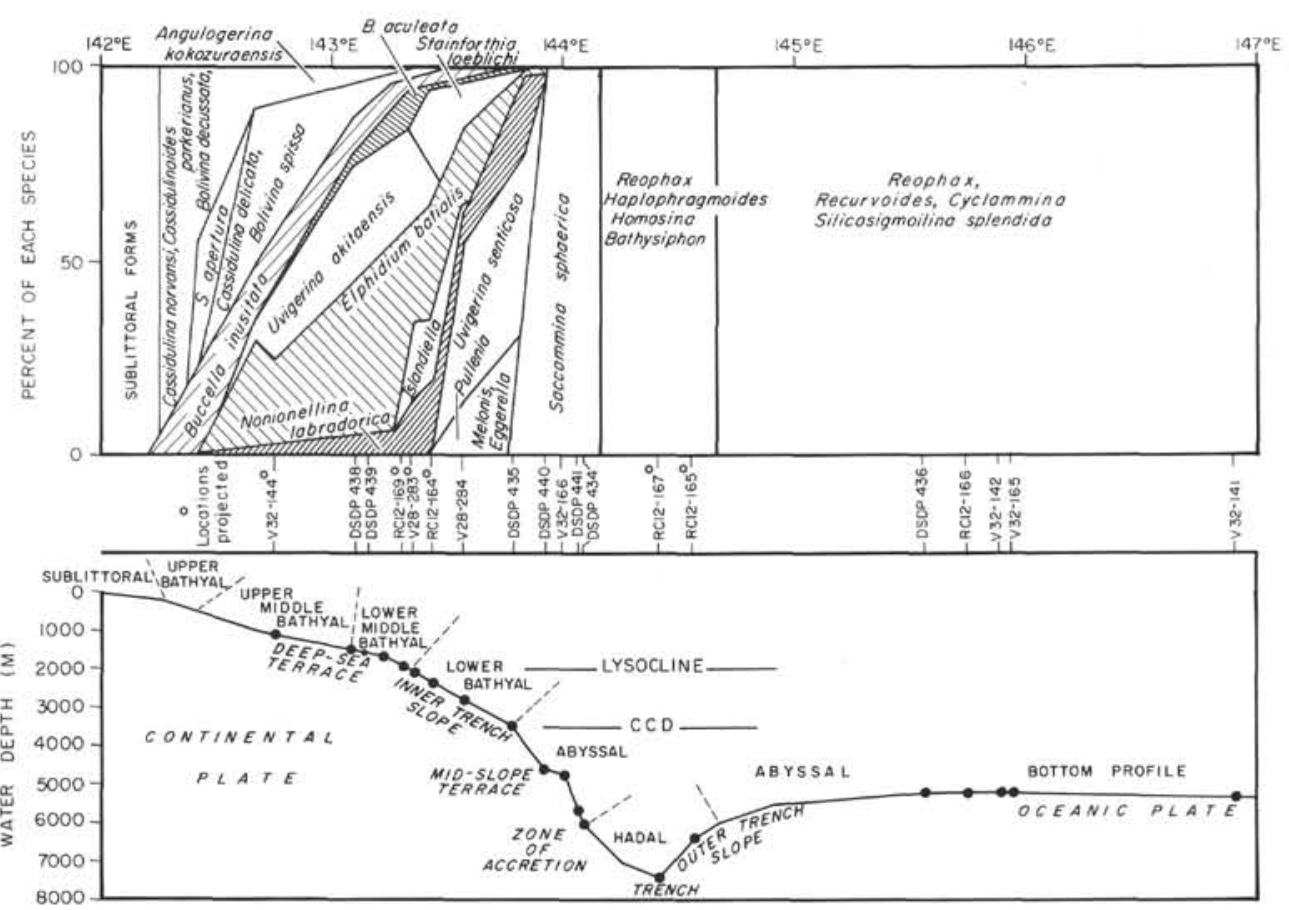

Figure 5. Relative frequency of benthic foraminifer assemblages along the Japan Trench transect. Samples marked by a star have been projected onto the transect line according to depth. 
benthic foraminifers seem to occur in the deepest parts of the biofacies in the Japan Trench.

Benthic foraminifer assemblages characterize the sediments of the Japan Trench area in two important ways: depth and location. Numerous sites across the face of the inner-trench shelf and slope permit the recognition of many depth-related biofacies with broad geographical continuity and narrow vertical extent. Great abundances and high species diversity throughout these samples show a gradual succession of shallow-water faunas subject to periodic climatic changes, deep-water calcareous faunas flanking the lysocline, and finally low-calcite agglutinated faunas below the CCD. Sediments on the oceanic plate differ markedly in faunal composition from those occupying comparable depths on the inner trench wall. The trench may be an effective barrier to lateral migration of many species, and even the subduction process itself may act as a limiting agent through time. The contrasting shelf-slope and oceanicplate assemblages thus identify the sediments of each part of the trench region and serve as major tracers for these sediments during subduction and the formation of the accretionary wedge.

\section{Martinottiella communis: LOCAL DISAPPEARANCE}

The agglutinated benthic foraminifer species Martinottiella communis d'Orbigny first appears at Site 436 (the site containing the longest benthic-foraminifer record at the Leg 56 sites) in the upper Miocene (Figure $6)$. It reaches its greatest abundance (6-10 tests per 10 $\pm \mathrm{cm}^{3}$ sample from Holes 434B and 436, as many as 34 tests in Section 435A-5-5) in the lower Pliocene. Although living in several areas of the Pacific today, it disappeared from the vicinity of the Japan Trench transect near the top of the Denticula kamtschatica diatom zone. Two isolated, broken specimens were found higher, in the $D$. seminae fossilis-D. kamtschatica Zone (Sections 435-13-2 and 435-13-4), and one in the Actinocyclus oculatus Zone (Section 435-9-2). The highest occurrence at Site 434 was in Section 434-7-1, at the top of the D. kamtschatica Zone, whereas at Site 436 the last occurrence was in Section 436-19-1, in the D. seminae fossilis-D. kamtschatica Zone (Figure 6). Echols (1973) recorded $M$. communis from Miocene and Pliocene sediments of the Bering Sea. There, its highest occurrence at DSDP Sites 184 and 185 was in the Thalassiosira zabelinae Zone (given as the $T$. zalzelinae Zone, now equivalent to the $D$. seminae fossilis Zone) of the late Pliocene, whereas at Sites 190 and 192 the extinction level was found in the $D$. seminae fossilis- $D$. kamtschatica Zone near the middle of the Pliocene. In northern Japan, Maiya (1975) gives the range of $M$. communis as extending from his "barren planktonic foraminifer zone" (late Miocene) to within the Globigerina pachyderma (dextral)-Globorotalia orientalis Zone (Pliocene). Thus, while M. communis appears to be a useful guide fossil to the late Miocene and early Pliocene, a chronostratigraphic level based on its disappearance would be unreliable. What we see, however, is an indication of the time when certain environmental conditions were eliminated during the Backbone Range orogeny of the late Tertiary in northern Ja-

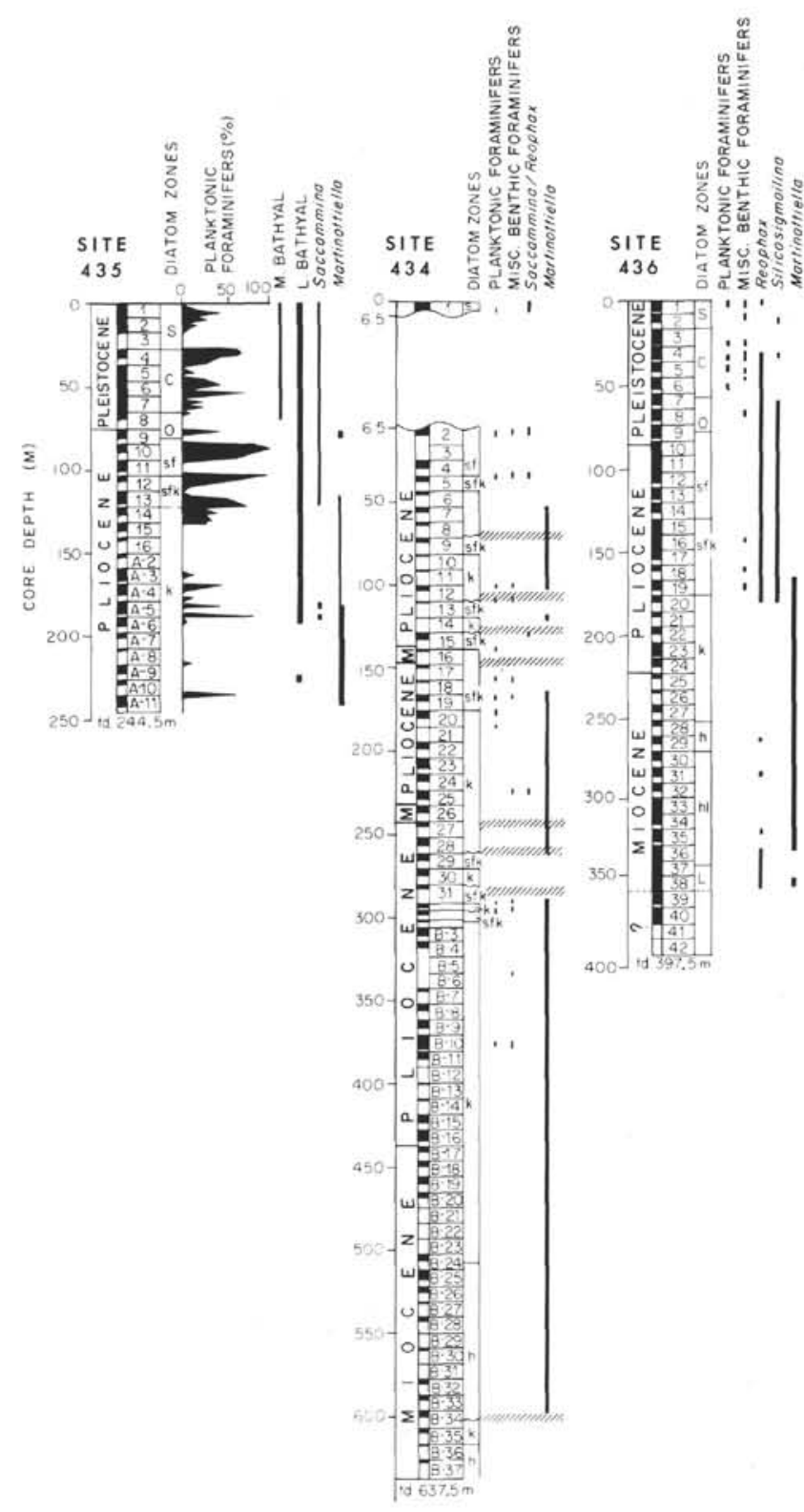

Figure 6. Comparison of DSDP Leg 56 sites, showing core recovery (shaded), diatom zones (Harper, this volume, after Koizumi, 1975), and ranges of foraminifer taxa. Hachures at Sites 434 indicate levels of possible faulting.

pan. Here, most workers infer that $M$. communis and its associated forms indicate middle bathyal depths in a closed-basin extending below the oxygen minimum (Asano et al., 1969). Uplift in various areas would have changed these conditions in a time-transgressive manner. The late disappearance of the species near the Japan Trench (Leg 56) sites and the even younger Leg 19 sites may be accounted for by the distance of these locations from the orogeny.

Following the disappearance of $M$. communis, Saccammina and (or) Reophax continue upward in the Leg 56 sections (single chambers of fragmented Reophax 
pilulifer are indistinguishable from Saccammina). These are accompanied at Site 436, of the oceanic plate, by Silicosigmoilina splendida n.sp., and at Sites 435 and 434 by low numbers of lower bathyal and abyssal forms. During the Pleistocene, planktonic foraminifers became more abundant at Site 435 as the site was raised above the CCD.

\section{SITE 434}

Site 434 was the deepest hole of the Japan Trench transect, at 5986 meters. The location was selected for penetration of sediments within the postulated zone of accretion at the foot of the landward wall. It also marks the limit between the abyssal and hadal biofacies.

Diatom biostratigraphy places the first core in the Pleistocene Denticula seminae Zone, unconformably underlain by the $D$. seminae fossilis Zone of the late Pliocene in the second core. A number of $N$. asanoi (Table 3) were identified in sample 434-2, CC, also implying the late Pliocene, although these individuals may have been displaced down-slope. Planktonic foraminifers were also found in Sample 434-13, CC; the assemblage is dominated by $G$. praeinflata and $N$. asanoi, indicating the late Pliocene at this level. A few rare specimens of planktonic species were found in samples from Hole 434B, but these were either very corroded or were heavily stained, as in Section 434B-10-3, which suggests reworking. In general, I believe that the occurrences of planktonic foraminifers at this site probably result from the displacement of up-slope faunas. Benthic-foraminifer assemblages from Holes 434 and 434B (434A was barren) contain elements of the upper bathyal, lower bathyal, and abyssal biofacies, without clear indications of hadal forms. It is important to note that the species which is apparently limited to the oceanic plate, $S$. splendida n. sp., was not found at Site 434. The eurybathyal species Reophax pilulifer was present in low frequencies. Thus, I find no conclusive evidence of oceanic-plate sediments at this site.

It is, however, necessary to explain the stratigraphic interval between 50 meters (434-6, CC) and 270 meters (434-29, CC). This interval is between the base of the $D$. seminae fossilis- $D$. kamtschatica Zone (proceeding downward from the top of the hole), and the top of the $D$. kamtschatica Zone (proceeding upward from the bottom of the hole). As discussed elsewhere (Harper, this volume), the diatom $D$. seminae fossilis has a patchy distribution through this interval. This, and the relatively poor recovery of highly fractured and compacted sediments, led us to speculate (Langseth, Okada, et al., 1978) that the upper Pliocene of Site 434 was thickened by a series of imbricate faults associated with the subduction process. The otherwise-thin upper Pliocene thus would be repeated several times through the stack of sediments. However, poor preservation of the diatoms, or pronounced climatic fluctuations, during this time, could have produced the same effect. Still, it seems unlikely that the great sediment accumulation observed here is entirely the result of normal hemipelagic depostion, especially in view of the two flanking Leg 56 sites with their contemporaneous intervals of far lesser accu- mulation. Figure 6 , comparing the biostratigraphy of Leg 56 sites, has been constructed to show the levels of possible repetition. There is the suggestion that the disappearance of $M$. communis and its succession by Saccammina and Reophax at Site 434 may also be repeated several times, but the frequency of specimens is extremely low.

\section{SITE 435}

Of the three Leg 56 sites, this produced the greatest number of foraminifers, which commonly exceed 100 specimens per $10-\mathrm{cm}^{3}$ sample; in several instances, over 2000 specimens were found (Tables 2 and 4). Planktonic foraminifers occur continuously down to Section 435A6-3, and in Cores 435A-9 and 435A-11 below that.

Temperate-latitude planktonic taxa useful in biostratigraphy are present throughout the hole. The combination of the extinctions of $N$. asanoi and $G$. orientalis and the appearance of $G$. inflata, places the Pliocene-Pleistocene boundary between Cores $435-8$ and $435-9$. The boundary between early and late Pliocene is indicated between Cores $435-13$ and $435-14$ by the first appearances of $G$. tosaensis and $T$. quinqueloba, but preservation in this interval is poor. I suggest an earlyPliocene age for the base of this hole on the basis of rare Sphaeroidinellopsis, early stages of the $G$. orientalis lineage, and forms which I call $G$. ikebei that are intermediate among $G$. puncticulata, $G$. suterae, and $G$. conoidea.

The last continuous occurrence of Martinottiella communis is in Section 435A-5-4, although very rare individuals persist to Section 435-9-2, in The A. oculatus diatom zone. The greater abundance of $M$. communis at this site relative to Site $\mathbf{4 3 4}$ and $\mathbf{4 3 6}$ demonstrates that it was a middle or lower bathyal species (Asano et al., 1969 , report it as upper middle bathyal).

Lower bathyal calcareous foraminifers (Eggerella bradyi, Nodosaria, Lagena, Oolina, Sphaeroidina, Globobulimina ovata, Pullenia bulloides, Melonis, Gyroidina, Pyrgo, Cibicides wuellerstorfi, Hoeglundina elegans, and Uvigerina senticosa) became more abundant (Core 435-16 and upward) as the site was uplifted above the CCD during the late Pliocene. The presence of lower middle bathyal forms (Globocassidulina, Oridorsalis, and Alabamina) suggest continued uplift through the Pleistocene which brought the site within the biogeographic range of these taxa. Upper middle bathyal foraminifers (Stainforthia, Cassidulinoides, Astrononion) and even shallower forms (Textularia, Quinqueloculina, Angulogerina, Bulimina aculeata, Uvigerina akitaensis) show that down-slope displacements of sediments were common. Large proportions of planktonic relative to benthic foraminifers also support this idea: ratios of planktonic to benthic taxa (Figure 4) show that Site 435, near the modern CCD, has about 5 per cent planktonic forms. In much of Hole 435, the planktonic-benthic ratio commonly reaches 20 per cent and often exceeds 60 per cent. Depression of the lysocline in response to climatic fluctuations has occurred in the past at equatorial latitudes (Thompson, 1976; Thompson and Sciarrillo, 1978). The coiling directions of $N$. pachyderma at 
TABLE 3

Foraminifers at DSDP Site 434

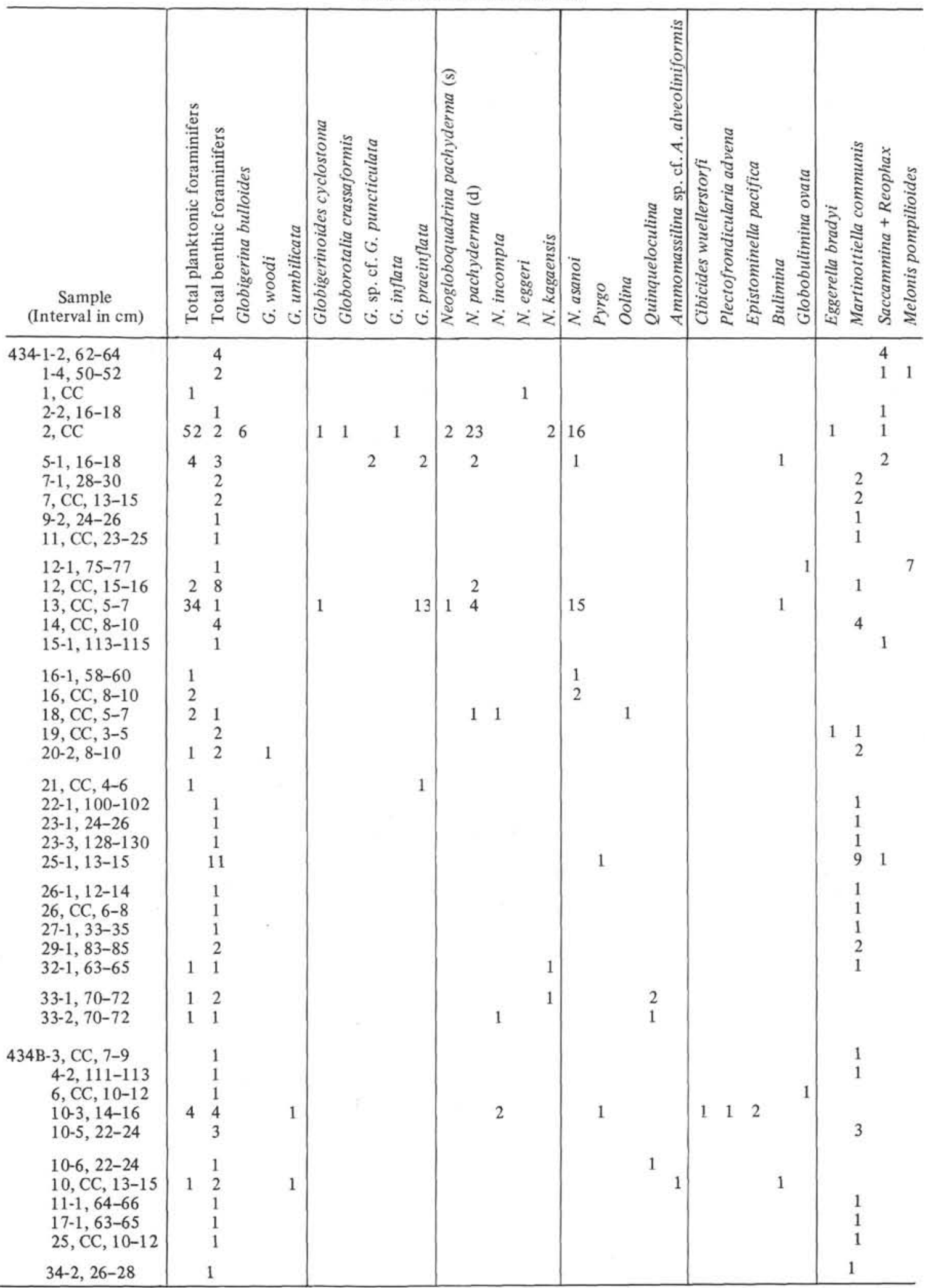


this site (Figure 3 ) shows that surface-water variations were pronounced during the Quaternary, which may have affected the lysocline here as well. The response of benthic taxa to climatic change, particularly for the North Pacific, is not known at present. The obvious association of benthic foraminifer distributions with water depth alone presently is being reinterpreted in terms of temperature, salinity, and oxygen content; the results (Lohmann, 1978; Streeter and Shackleton, 1978) suggest complicated relationships between species and their environments that can be used to monitor hydrographic changes through time.

The foraminifer data for Site 435 indicate at least three major processes: (1) climate-related fluctuations in physical parameters of surface waters, which may have shifted the lysocline, indicated by planktonic-foraminifer variations; (2) elevation of the site above the CCD (it may be rising still), indicated by calcareous benthic foraminifers and (3) down-slope displacement of sediments, indicated by sporadic middle bathyal texa.

\section{SITE 436}

Planktonic and upper bathyal benthic foraminifers were recovered from Pleistocene sediments (diatom age determinations) of Site 436 in association wih ice-rafted pebbles (Table 5). Dissolution has destroyed other calcareous tests which might have accumulated.

As discussed elsewhere, Martinottiella communis ranges from the late Miocene through early Pliocene and is succeeded in the late Pliocene by Reophax pilulifer and Silicosigmoilina splendida n. sp. Petelin (1970) noted that agglutinating species are often selective about the minerals chosen for their tests. It is possible that the appearance of agglutinating taxa during the late Miocene of the North Pacific may be related to orogenic events in Japan; if so, the first local occurrences depended upon the time when detrital minerals reached various parts of the region.

The middle Miocene through the Paleogene is condensed in a zeolitic pelagic clay interval between 360 and 380 meters. Washed residues consist of zeolites, fish bones and teeth, and manganese micronodules. Some of the micronodules in Section 436-39-6 were split and found to exhibit external molds of small globigerinid or globorotaliid foraminifers (Plate 9). I have not been able to identify the species because of their small size; they may represent juvenile stages. This occurrence, however, bears importantly on ideas of manganesenodule formation. The exceedingly great water depth indicated by the pelagic clay is supposed to cause the total dissolution of any calcareous and siliceous microfossils in a very short time. For the molds to form, precipitation of the manganese about the foraminiferal nucleation point before the test was destroyed must have been rapid indeed. The lack of large nodules is also impor- tant; they may not form under the same conditions as do micronodules.

\section{DESCRIPTION OF NEW TAXA}

Family GLOBOROTALIIDAE Cushman, 1927

Genus Globorotalia Cushman, 1927

Globorotalia wilesi Thompson, n. sp. Plate 4, Figures 1-3

Globorotalia sp. Parker, 1964, p. 631; pl. 102, figs. 20-22; Rogl and Bolli, 1973, p. 569; pl. 7, figs, 1-4; pl. 16, fig. 4.

Globorotalia scitula Brady, Keller, 1978, pp. 101,103; pl. 4, figs. 9-11.

Description: Test free, small, biconvex, about 14 subglobular chambers arranged in a low trochospire of about three whorls, $41 / 2$ to 5 chambers in the final whorl. Chambers increasing gradually in size with growth, partially embracing, slightly inflated on the spiral side, moderately inflated on the umbilical side. Equatorial periphery lobulate; axial profile moderately biconvex, the final chamber more ventrally inflated than the earlier chambers. No true carina present, although the acutely rounded peripheral edges of the chambers are imperforate. Intercameral sutures on both spiral and umbilical sides simple and curved; spiral suture slightly lobulate. Aperture interiomarginal, umbilical-extraumbilical, a symmetrical arch of moderate height at the base of the strong umbilical shoulder, bordered by an imperforate apertural rim. Wall calcareous, perforated with large pores, the pores concentrated mostly on the spiral side away from the test margin; pore diameter variable, with a tendency to be larger on the early whorls; pore shape subcircular. Surface shiny, translucent, sparsely and irregularly pustulate, the isolated pustules mostly on the umbilical side of the early chambers in the final whorl. Coiling is almost invariably dextral.

Remarks: Parker (1964) recognized this species as new, but was reluctant to describe it from the few specimens recovered from the Experimental Mohole Site off Mexico. She did note the small size of the test, its slighty curving sutures, and translucent test wall with relatively large pores. RogI and Bolli (1973) compared their Caribbean form to $G$. crassaformis and $G$. scitula, but did not propose it as a separate taxon because of the close similarities to these two species. It is, as they suggested, most similar to G. scitula, which has, however, much larger and more closely spaced pores, usually with a funnelshaped pore depression, and the test has a very weakly lobulate equatorial outline. Because $G$. wilesi has been found often in North Pacific sediment samples without G. scitula and G. hirsuta (Thompson, 1977), it is inferred that $G$. wilesi probably is not an immature stage of either species. It is common in the region of the temperate North Pacific beneath the Kuroshio current, and migrated to tropical latitudes during glacial ages of the Pleistocene. This species was first described in an unpublished work by Thompson (1977). It is therefore redescribed here, with redesignation of the primary types. The species is named in honor of the late Dr. William E. Wiles of the Department of Geology, Rutgers University.

Occurrence: This species has been observed mostly in the North Pacific between latitudes 24 and $45^{\circ} \mathrm{N}$, less commonly in the South Pacific between latitudes 17 and $40^{\circ} \mathrm{S}$, and rarely in the Indian Ocean and Caribbean. The geologic range observed by Parker (1964) at the Guadalupe site is approximately Pliocene to recent. At DSDP Site 435 , it occurs sporadically down to Section 435A-5-3 (Plate 4, Figures $3 \mathrm{a}, \mathrm{b})$. At this level, the periphery is conspicuously more acute and the umbilical shoulder more inflated than in younger sediments, suggesting an early Pliocene base of the range.

Size: Maximum observed diameter $0.2 \mathrm{~mm}$.

Holotype: USNM 239939 (Plate 4, Figures 1a, b).

Paratypes: USNM 239940 (Plate 4, Figures 3a, b).

Type Locality: Northwest Pacific Ocean, DSDP Site 435, Sample 435-12-1, 65-67 cm (sub-bottom depth $104 \mathrm{~m}$ ). 
TABLE 4

Benthic Foraminifers at DSDP Site 435

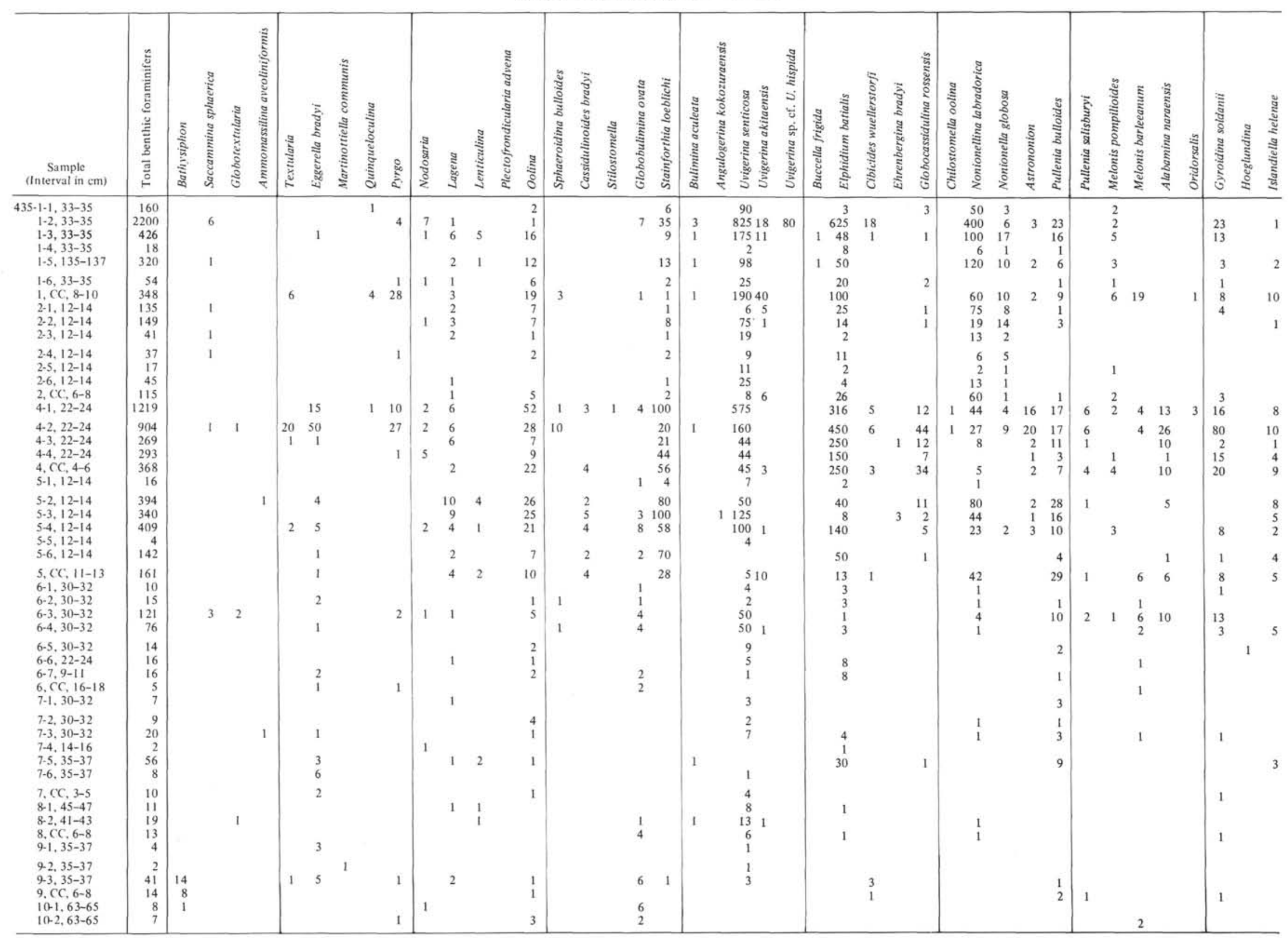


TABLE 4 - Continued

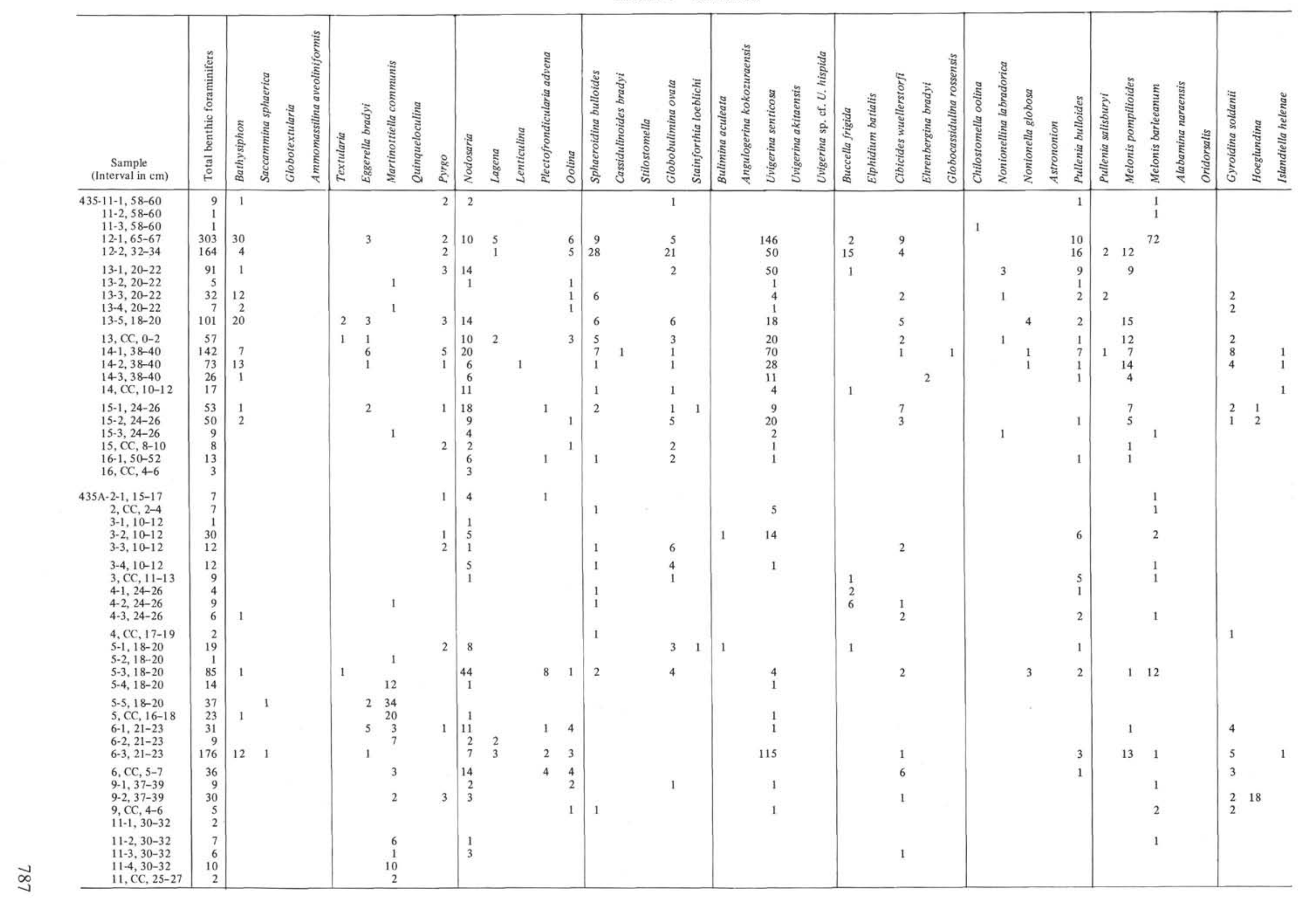

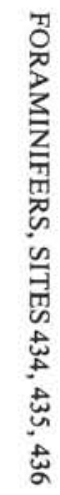


TABLE 5

Foraminifers at DSDP Site 436

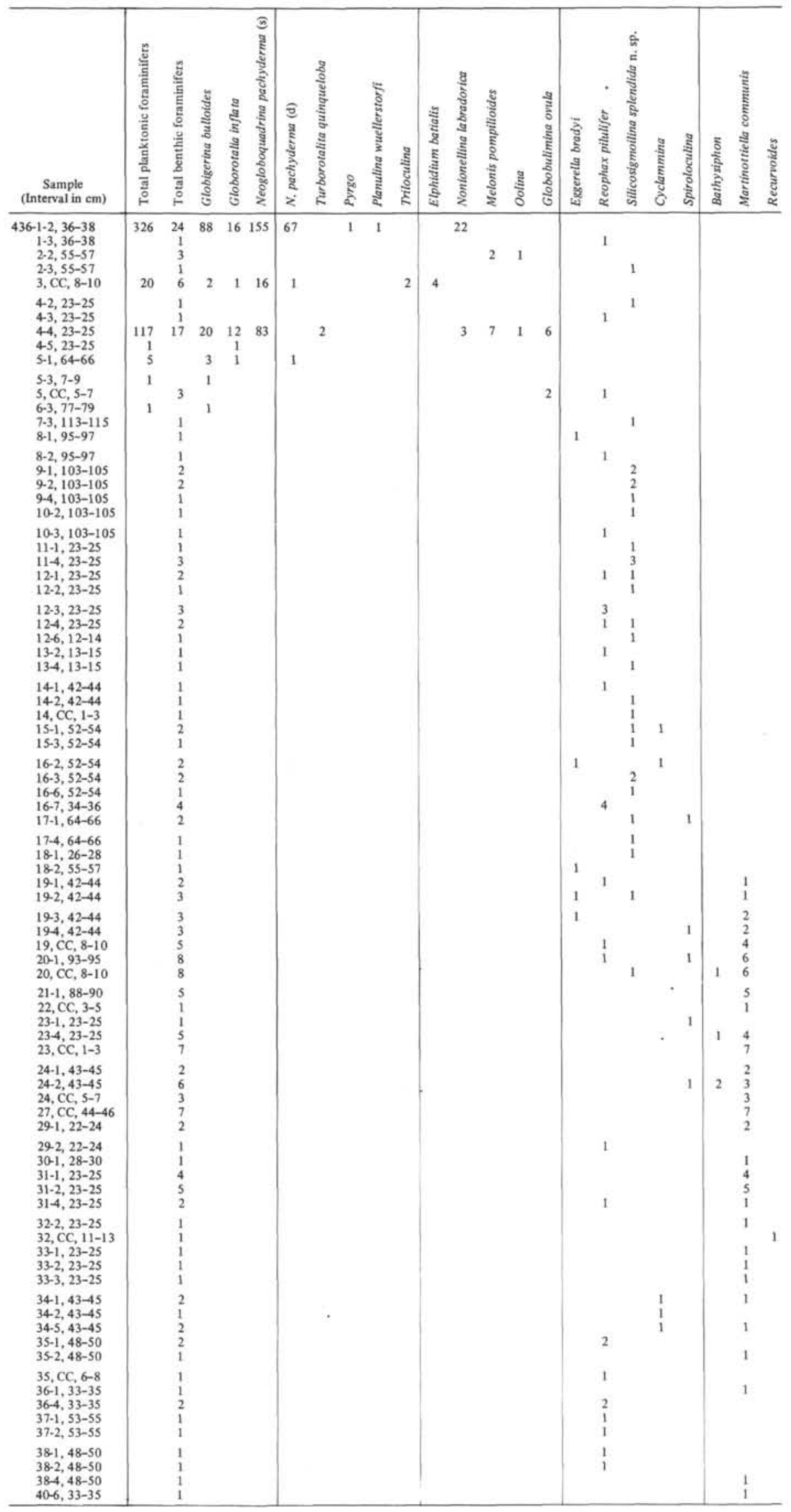


Family RZEHAKINIDAE Cushman, 1933

Genus Silicosigmoilina Cushman and Church, 1929

Silicosigmoilina splendida Thompson, $\mathrm{n}$. sp.

Plate 8, Figures 16, 17

Miliolina labiosa (d'Orbigny), Brady, 1884, pp. 61,99-102,170 [not pl. 6 , figs. $3-5$ ]; Belyaev, 1966 , p. 37 ; table 4 , no. 55 .

Miliolinella sp. Echols, 1964, p. 157; pl. 12, fig. 1.

Description: Test free, small, about 3 to 5 chambers planispirally arranged, each chamber extending halfway around the coil, so that there are two per whorl and the aperture is alternately at opposite ends of the test. The chambers are well inflated at the apertural end, narrowing considerably at the aboral end; there is strong embracement of the previous chambers. The aperture is a simple, crescentic opening at the base of the final chamber, slightly raised above the test surface, and often showing a slight protrusion of the wall material into the opening. Sutures distinct, but weakly incised. Wall thin, translucent to transparent, made of opaline silica, imperforate.

Remarks: Brady found a number of these small, iridescent, noncalcareous milioline foraminifers at his North Pacific sites, but placed it along with Triloculina labiosa d'Orbigny into Miliolina labiosa. His definition (Brady, 1884, p. 61) is rather broad: "test imperforate; normally calcareous and porcelanous, sometimes encrusted with sand; under starved conditions (e.g., in brackish water), becoming chitinous or chitinoarenaceous; at abyssal depths occasionally consisting of a thin, homogeneous, imperforate, siliceous film." He later noted (p. 100 ) that the silica is "unaffected by acids, and iridescent when first taken out of spirit," and that (p. 170) "they occasionally collapse on being taken out of the fluid and allowed to dry." The specimens Brady chose to illustrate (Brady, 1884, pl. 6, figs. 3-5) do not include any of the iridescent siliceous forms, and are probably $M$. labiosa. The iridescent siliceous type are believed to be synonymous with the specimens recovered from DSDP Site $\mathbf{4 3 6}$ and from several LamontDoherty piston cores in the North Pacific. The description of typical Silicosigmoilina by Cushman and Church (fide Ellis and Messina, 1940 et seq.) states that this genus has a finely arenaceous wall with siliceous cement, although Loeblich and Tappan (1954, p. C220) include in Family Rzehakinidae forms with siliceous or agglutinated walls. Species subsequently assigned to Genus Silicosigmoilina are mostly from the Cretaceous (fide Ellis and Messina, 1940 et seq.). As a result, the species here called splendida (because of its iridescence) is placed in Silicosigmoilina only for convenience. Adequate study of this species and other siliceous benthic foraminifers (Resig, 1974) probably will lead eventually to the establishment of a higher category of silica-secreting foraminifers.

Occurrence: The biostratigraphic range of $S$. splendida at DSDP Site 436 is from the late part of the Denticula kamtschatica Zone (middle Pliocene), in Section 436-20, CC, to the recent. It was observed by Brady (1884, pp. 99-102) at seven stations in the North Pacific between latitudes 12 and $38^{\circ} \mathrm{N}$ and longitudes $144^{\circ} \mathrm{E}$ to $152^{\circ} \mathrm{W}$, between 2050 and 3950 fathoms $(3750-7225 \mathrm{~m})$.

Size: Maximum observed diameter $0.2 \mathrm{~mm}$.

Holotype: USNM 239941 (Plate 8, Figures 16, 17).

Type Locality: Northwest Pacific Ocean, DSDP Site 436, Sample 436-9-1, 103-105 cm (sub-bottom depth $75 \mathrm{~m}$ ).

\section{ACKNOWLEDGMENTS}

I would like to thank S. Stephen Streeter (Lamont-Doherty Geological Observatory) and James C. Ingle, Jr., (Stanford University) for critically reviewing this paper, and Gerta Keller (Stanford University) for valuable discussions in light of her Leg 57 data. Dee L. Breger prepared the SEM illustrations, and Barbara Walter drew the figures.

Samples from the Lamont-Doherty Geological Observatory Core Collection were provided through Office of Naval Research grant ONR N00014-75-C-0210 and National Science Foundation grant NSF OCE-76-18049. This study was supported by National Science Foundation grant NSF OCE-7518136 and Office of Climate Dynamics grant NSF OCE-7519627.

\section{REFERENCES}

Asano, K., Ingle, J. C., and Takayanagi, Y., 1969. Neogene planktonic foraminiferal sequences in northeastern Japan. In Brönniman, P., and Renz, H. H. (Eds.), Proceedings of the First International Conference on Planktonic Microfossils: Leiden (E. J. Brill), pp. 14-25.

Bandy, O. L., Frerichs, W., and Vincent, E., 1967. Origin, development, and geologic significance of Neogloboquadrina Bandy, Frerichs \& Vincent, gen. nov. Contr. Cushman Foundation Foraminiferal Res., 18, pt. 4, 152-157.

Banner, F. T., and Blow, W. H., 1960. Some primary types of species belonging to the superfamily Globigerinaceae. Contr. Cushman Foundation Foraminiferal Res., 11, pt. 1, 1-41.

Belyaev, G. M., 1966. Hadal bottom fauna of the world ocean: Moscow (Nauka) [English translation by the Israel Program for Scientific Translations, Jerusalem, 1972].

Blow, W. H., 1969. Late middle Eocene to Recent planktonic foraminiferal biostratigraphy. In Brönniman, P., and Renz, H. H. (Eds.), Proceedings of the First International Conference on Planktonic Microfossils: Leiden (E. J. Brill), pp. 199-421.

Brady, H. B., 1884. Report on the Foraminifera dredged by H. M. S. Challenger during the years 1873-1876. Report on the Scientific Results of the H. M. S. Challenger during the years 1873-1876, London, Zoology, v. 9, pt. 22, 814 p.

Echols, D. J., 1964. Distribution of foraminifera in sediments of the Scotia Sea area, Antarctic waters. Antarctic Res. Ser., 15, 93-168.

1973. Foraminifera, Leg 19, Deep Sea Drilling Project. In Creager, J. S., Scholl, D. W., et al., Init. Repts. DSDP, 19: Washington (U.S. Govt. Printing Office), pp. 721-735.

Ellis, B. F. and Messina, A. R., 1940 et seq. Catalogue of Foraminifera: New York (Am. Museum Nat. Hist.).

Ikebe, N., Takayanagi, Y., Chiji, M., and Chinzei, K., 1972. Neogene biostratigraphy and radiometric time scale of Japan-an attempt at intercontinental correlation. Pacific Geol. 4, 39-78.

Ikebe, N., and the Working Group on Neogene Biostratigraphy and Radiometric Dating in Japan, 1977. Summary of bio- and chronostratigraphy of the Japanese Neogene. In Saito, T., and Ujiié, H. (Eds.), Proceedings of the First International Congress on Pacific Neogene Stratigraphy, Tokyo, 1976: Tokyo (Kaiyo Shuppan), pp. 92-114.

Keller, G., 1978. Late Neogene biostratigraphy and paleoceanography of DSDP Site 310 Central North Pacific and correlation with the southwest Pacific. Mar. Micropaleont., 3, 97-119.

Kent, D. V., Opdyke, N. D., and Ewing, M., 1971. Climatic change in the North Pacific using ice-rafted detritus as a climatic indicator. Bull. Geol. Soc. Am., 82, 2741-2754.

Kitazato, H., 1977. Vertical and lateral distributions of benthic foraminiferal fauna and the fluctuation of warm and cold waters in the middle Pleistocene of the Boso Peninsula, Central Japan. Science Reports of the Tohoku University, Sendai, Second Series (Geology), 47, no. 1, 7-41.

Koizumi, I., 1975. Late Cenozoic diatom biostratigraphy in the circum-Pacific region. J. Geol. Soc. Japan, 81, 611627.

Langseth, M., Okada, H., et al., 1978. Near the Japan Trench: transects begun. Geotimes, March, 1978, 22-26.

Loeblich, A. R., Jr., and Tappan, H., 1964. Protista 2: Sarcodina, chiefly "thecamoebians" and Foraminifera. In Moore, R. C. (Ed.), Treatise on Invertebrate Paleontology, Part C: Lawrence, Kansas (Geol. Soc. Am.). 
Lohmann, G. P., 1978. Abyssal benthonic Foraminifera as hydrographic indicators in the western South Atlantic Ocean. J. Foraminiferal Res., 8, 6-34.

Maiya, S., 1975. Biostratigraphic study of late Cenozoic planktonic Foraminifera in the oil-producing region of northern Japan, Japan Petroleum Exploration Co., Technical Research Institute Spec. Pub. No. 35. [in Japanese].

Maiya, S., Saito, T., and Sato, T., 1976. Late Cenozoic planktonic foraminiferal biostratigraphy of northwest Pacific sedimentary sequences. In Takayanagi, Y., and Saito, T. (Eds.), Progress in Micropaleontology. New York (Am. Museum Nat. Hist.), pp. 395-422.

Matoba, Y., 1977. Recent foraminiferal assemblages off Sendai, Northeastern Japan. In Schafer, C. T., and Pelletier, B. R. (Eds.), First International Symposium on Benthonic Foraminifera of Continental Margins, Maritime Sediments, pp. 205-220.

Parker, F. L., 1964. Foraminifera from the experimental Mohole drilling, near Guadalupe Island, Mexico. J. Paleont., 38, 617-636.

Parker, F. L., and Berger, W. H., 1971. Faunal and solution patterns of planktonic Foraminifera in surface sediments of the South Pacific. Deep-Sea Res., 18, 73-107.

Petelin, V. P., 1970. Composition of agglutinated material in the shells of certain modern Foraminifera. Oceanology, 10, 46-55.

Resig, J. M., 1974. Siliceous foraminifera. Abstracts 1974 Ann. Mtg., Geol. Soc. Am., 6, 7, 924.

Saidova, Kh. M., 1966. Benthic foraminiferal faunas of the Pacific. Oceanology, 6, 222-227.

Shackleton, N. J., and Opdyke, N. D., 1973. Oxygen isotope and paleomagnetic stratigraphy of Equatorial Pacific core V28-238: oxygen isotope temperatures and ice volumes on a $10^{5}$ and $10^{6}$ year scale. Quaternary Res. 3, 39-55.

Shinbo, K., and Maiya, S., 1971. Neogene Tertiary planktonic foraminiferal zonation in the Japanese oil producing pro- vinces. In ECAFE Petroleum Symposium, Canberra, 1969: New York (United Nations) pp. 135-142.

Srinivasan, M. S., and Kennett, J. P., 1976. Evolution and phenotypic variation in the late Cenozoic Neogloboquadrina dutertrei plexus. In Takayanagi, Y., and Saito, T. (Eds.), Progress in Micropaleontology: New York (Am. Museum Nat. Hist.), pp. 329-355.

Streeter, S. S., and Shackleton, N. J., 1978. Paleocirculation of the deep North Atlantic: a 150,000 year record of benthic Foraminifera and ${ }^{18} \mathrm{O}$. Science, 203, 168-171.

Thompson, P. R., 1976. Planktonic foraminiferal dissolution and the progress toward a Pleistocene Equatorial Pacific transfer function. J. Foraminiferal Res., 6, 208-227. 1977. Pleistocene and Recent Foraminifera of the western Pacific Ocean: biostratigraphy, dissolution and paleoecology [D. Sc. thesis]. Tohoku University, Sendai, Japan.

1978. Late Tertiary planktonic foraminiferal datum biostratigraphy of the western North Pacific. IGCP Project 114, Biostratigraphic Datum-Planes of the Pacific Neogene, Third Working Group Meeting, Stanford, California, 60-61. (Abstract)

Thompson, P. R., and Sciarrillo, J. R., 1978. Planktonic foraminiferal biostratigraphy in the Equatorial Pacific. Nature, 276, 29-33.

Thompson, P. R., and Shackleton, N. J., 1979. North Pacific paleoceanography: late Quaternary coiling directions of Neogloboquadrina pachyderma. Trans. Am. Geophys. Union, 60 (18), 277. (Abstract)

Tully, J. P., 1964. Oceanographic regions and processes in the seasonal zone of the North Pacific Ocean. In Yoshida, K. (Ed.), Studies on Oceanography: Seattle (Univ. Wash. Press), pp. 68-84.

Vincent, E., 1975. Neogene planktonic Foraminifera from the Central North Pacific, Leg 32, Deep Sea Drilling Project. In Larson, R. L., Moberly, R., et al., Init. Repts. DSDP, 32: Washington (U.S. Govt. Printing Office), 765-801.

\section{PLATE 1}

Figures 1-4 Globigerina bulloides d'Orbigny.

$1-3$. Sample 435-1-5, 135-137 cm. $\times 150$.

4. Sample 435-9-3, 35-37 cm. $\times 140$.

Figures 5-7 Globigerina umbilicata Orr and Zaitzeff.

5-6. Sample 435-9-3, 35-37 cm. $\times 100$.

7. Sample 435-13-CC, $0-2 \mathrm{~cm} . \times 100$.

Figure $8 \quad$ Globigerinita glutinata (Egger).

Sample 435-1-5, 135-137 cm. $\times 140$.

Figures 9, 10 Globigerina umbilicata Orr and Zaitzeff.

Sample 435-13-CC, 0-2 cm. $\times 140$. 
PLATE 1

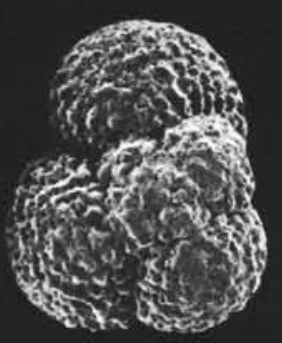

1a

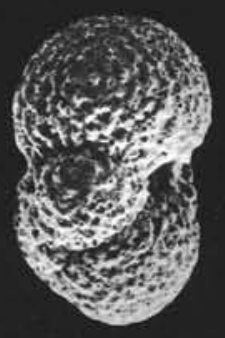

16

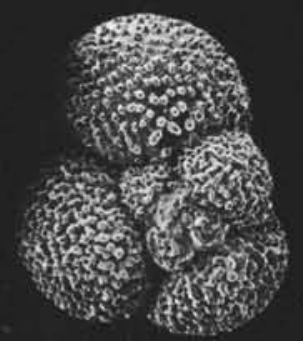

$2 a$

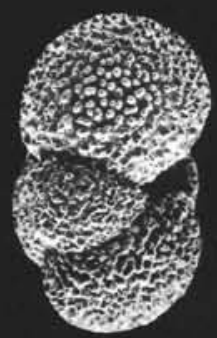

$2 b$

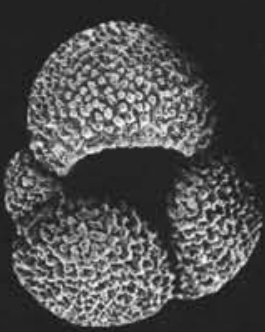

$2 c$

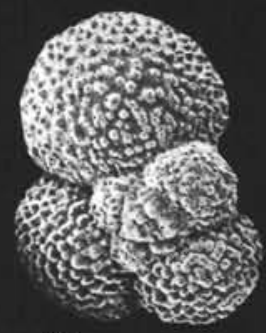

$3 a$
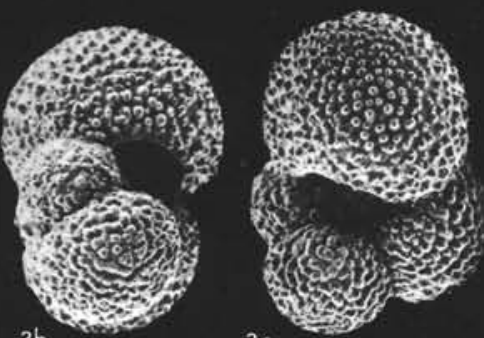

36
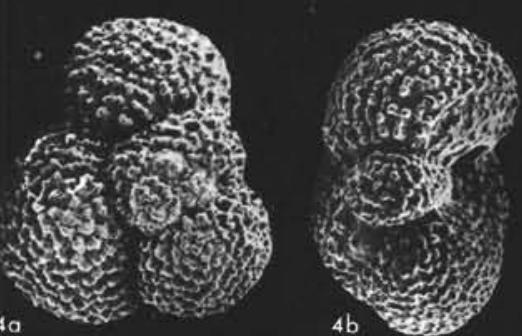

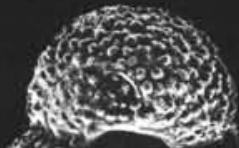

Af 200

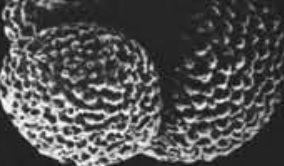

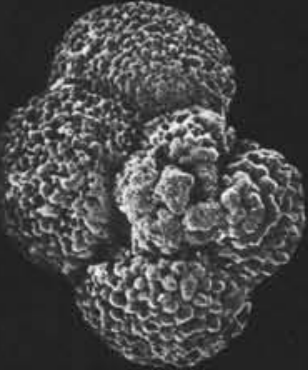

$5 a$

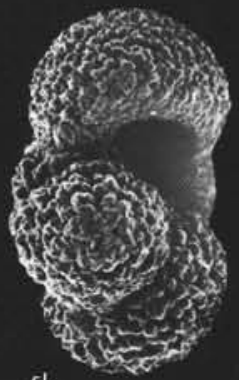

$5 b$

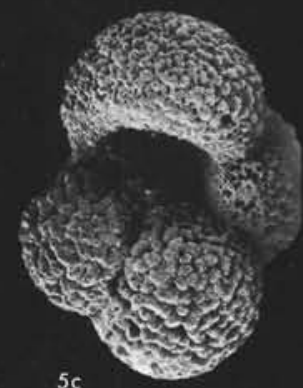

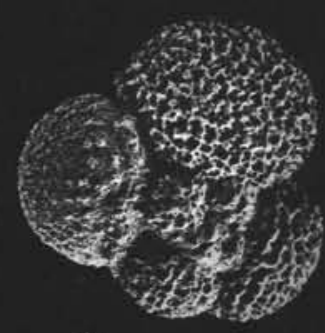

$6 a$

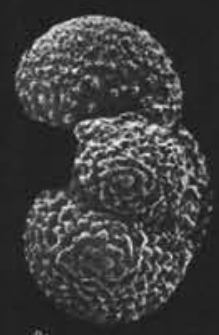

86

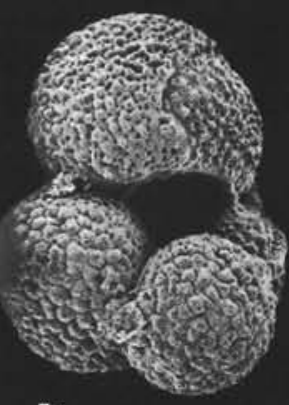

$7 \mathrm{a}$

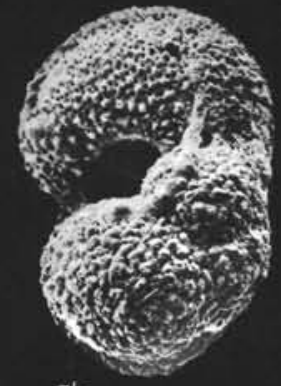

$7 b$

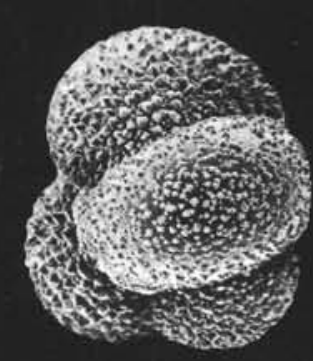

$8 \mathrm{a}$

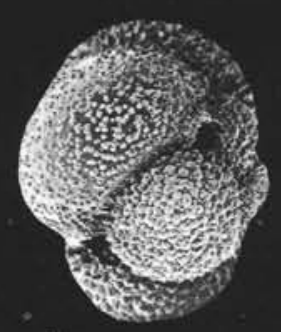

$8 b$

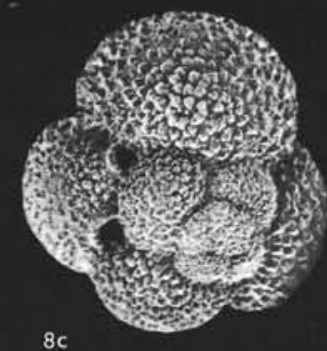

$8 c$

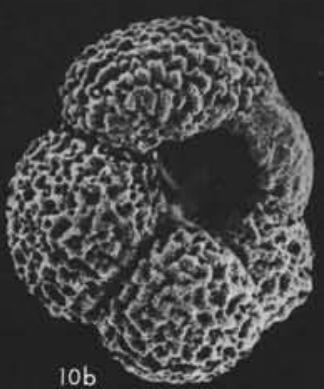




\section{PLATE 2}

Figure $1 \quad$ Globigerinoides trilobus (Reuss). Sample 435-13,CC, 0-2 cm. $\times 150$.

Figure 2 Globigerinoides ruber (d'Orbigny). Sample 435-1-5, 33-35 cm. $\times 185$.

Figure 3 Globigerinoides obliquus (Bolli). Sample 435-13,CC, 0-2 cm. $\times 190$.

Figures 4, 5 Globoquadrina altispira (Cushman and Jarvis). Sample 453A-6-1, 21-23 cm. ×180. 

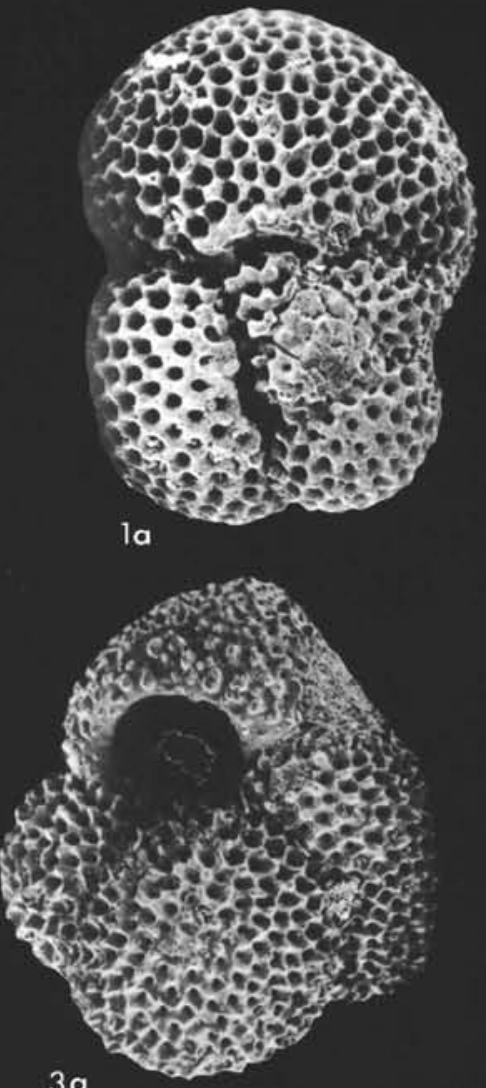

$3 a$

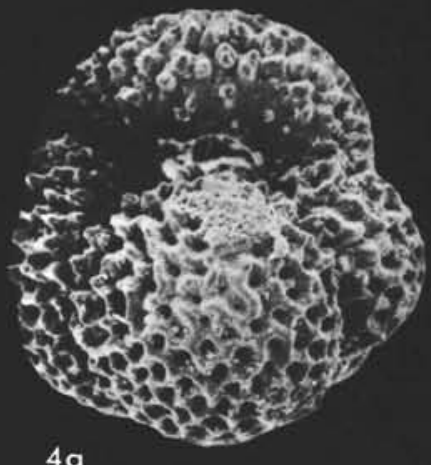

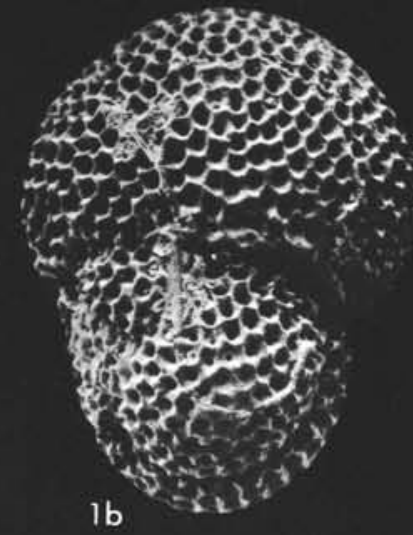

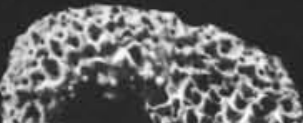

in)

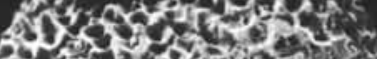
R. s.thr

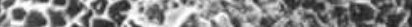

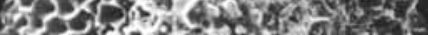

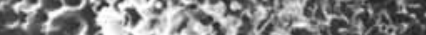

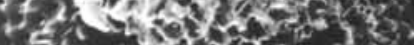

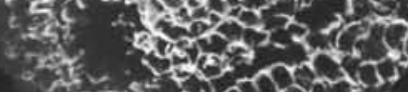

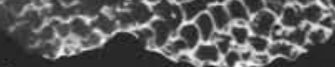

$3 \mathrm{~b}$

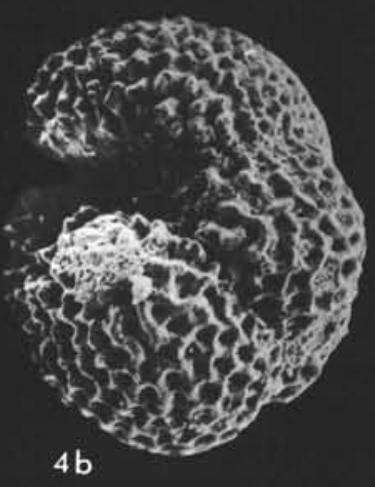

(f) Eif

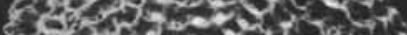

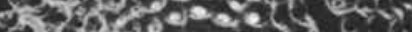

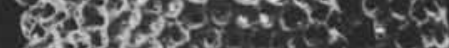

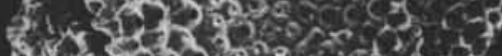

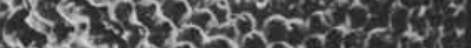

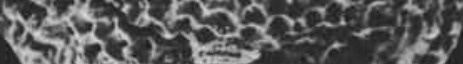

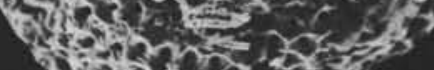

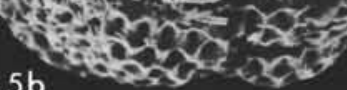
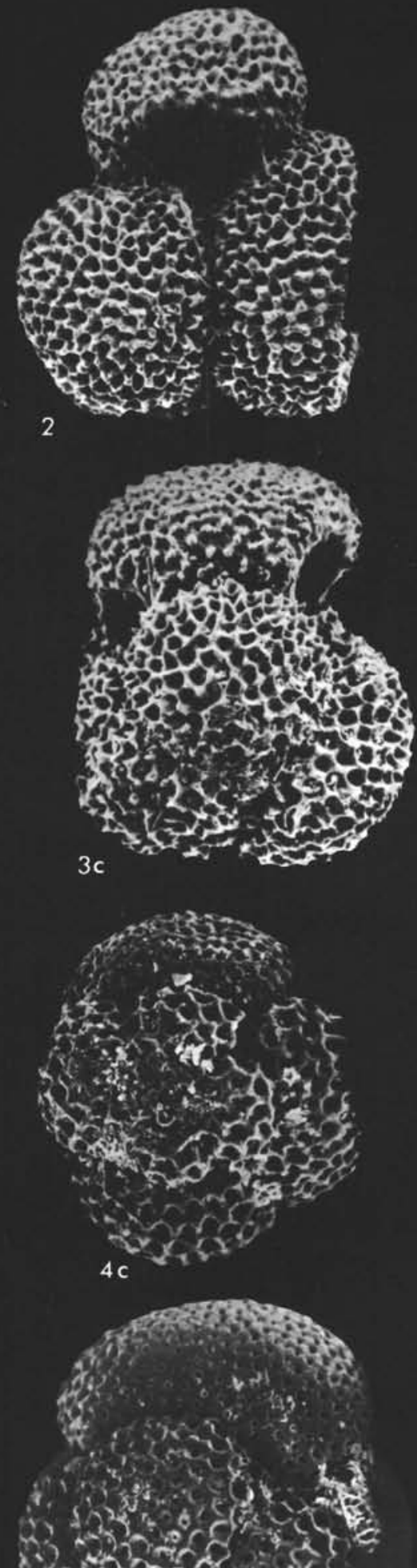

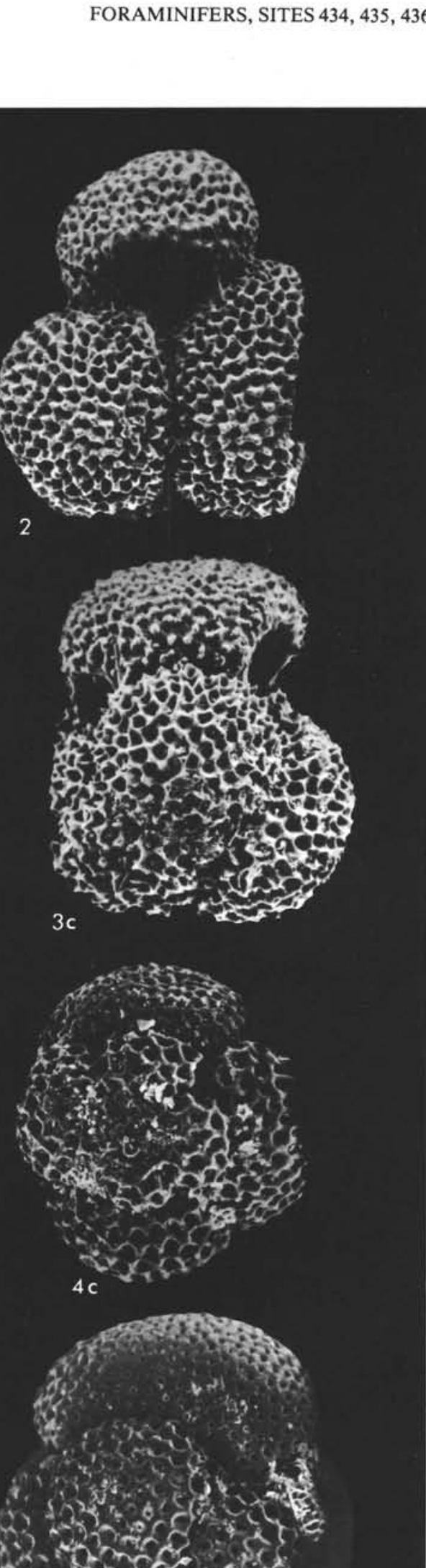

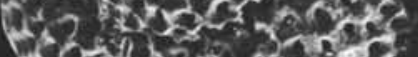

(r) a d a

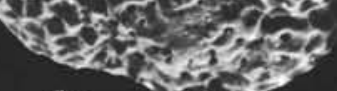

$5 c$ 


\section{PLATE 3}

Figures 1-5 Neogloboquadrina pachyderma (Ehrenberg). Sample 435-1-5, 33-35 cm.

$1-3$. Sinistrally coiled form. $\times 145$.

4-5. Dextrally coiled form. $4 . \times 170.5 . \times 155$.

Figure $6 \quad$ Neogloboquadrina eggeri (Rhumbler).

Sample 435-9-3, 35-37 cm. $\times 85$.

Figures 7, 8 Neogloboquadrina? incompta (Cifelli?).

Sample 435-9-3, 35-37 cm. $\times 150$.

Figure 9 Neogloboquadrina himiensis (Maiya, Saito, and Sato).

Sample 435-14-1, 38-40 cm. $\times 75$.

Figures 10-12 Neogloboquadrina asanoi (Maiya, Saito, and Sato).

Sample 435-13,CC, 0-2 cm. $\times 115$. 
PLATE 3
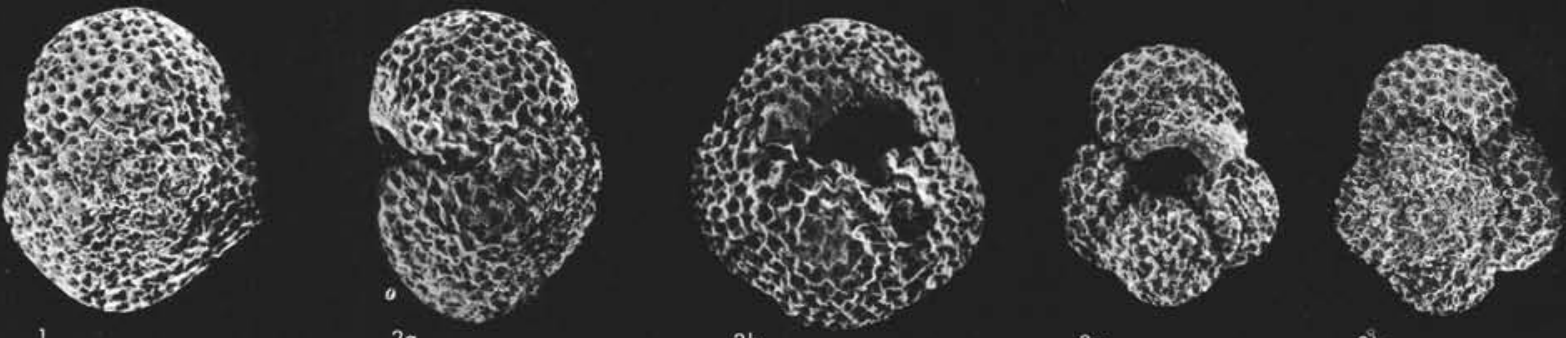

$2 a$

$2 b$

$3 a$

$3 \mathrm{~b}$
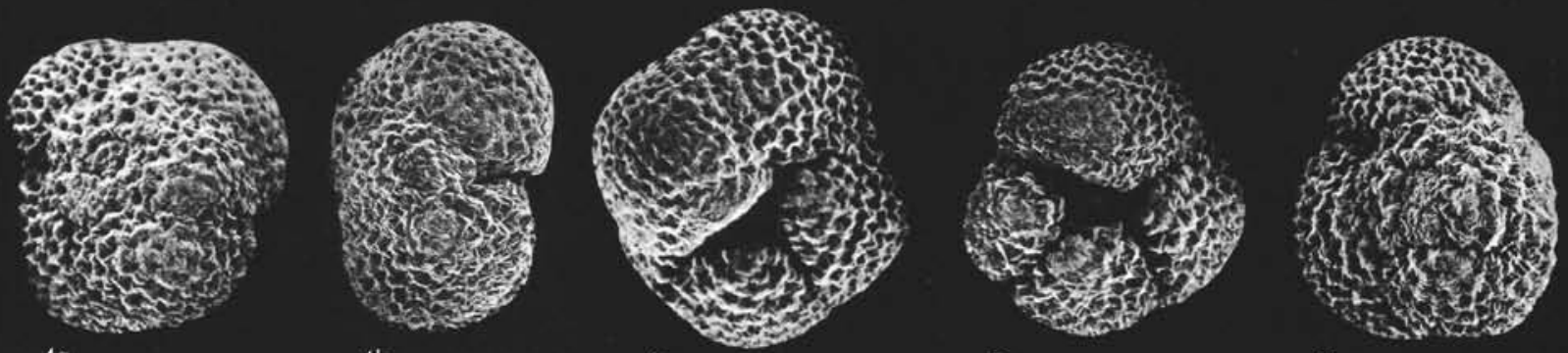

$4 a$

$4 \mathrm{~b}$
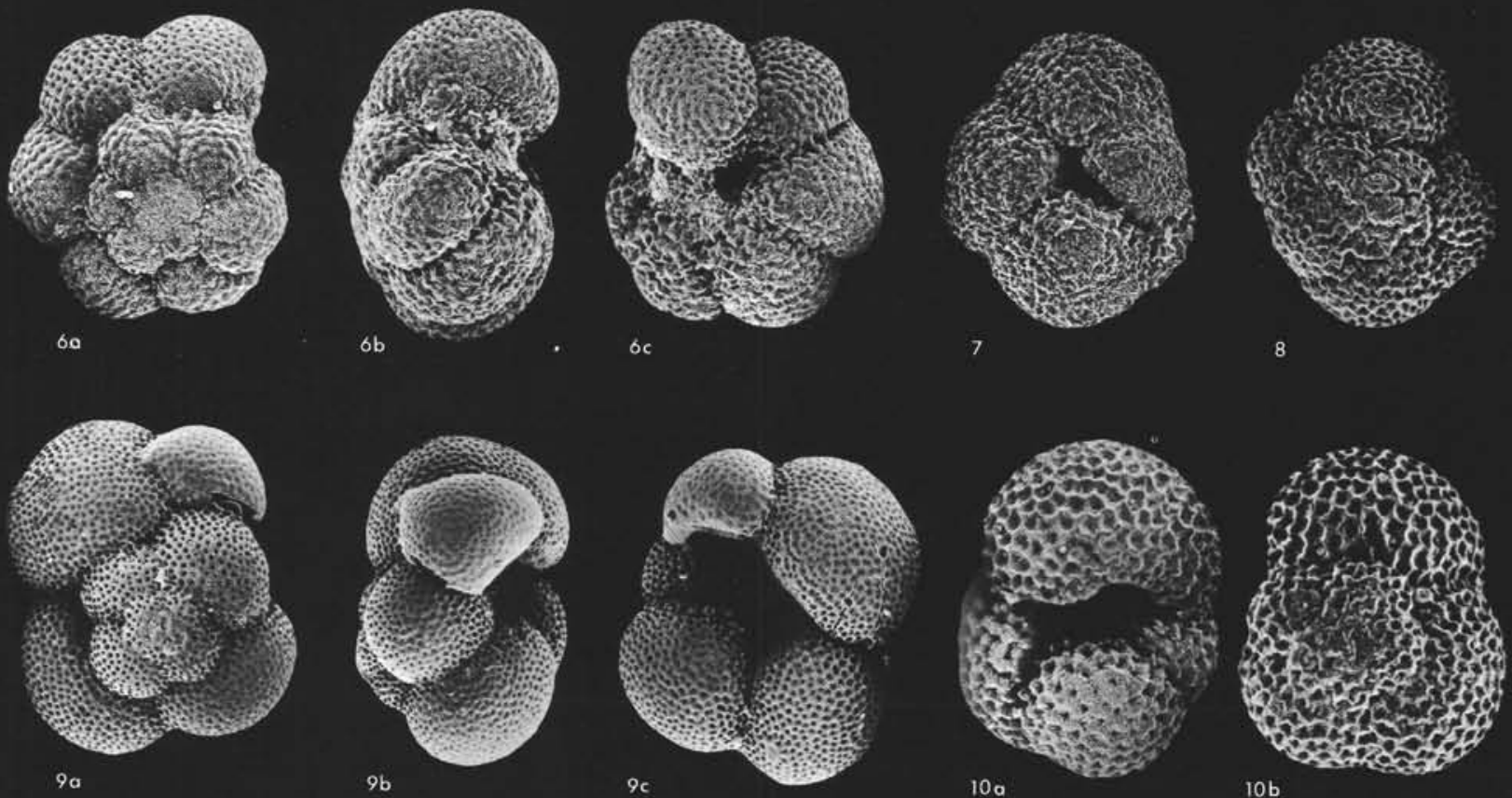

4 13.

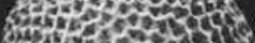

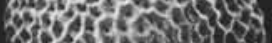

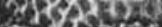

sor. 30.536 is $4325^{2}$ in

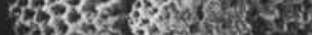
$335-25-5$ 35 -

भis ituxy

$11 \mathrm{a}$
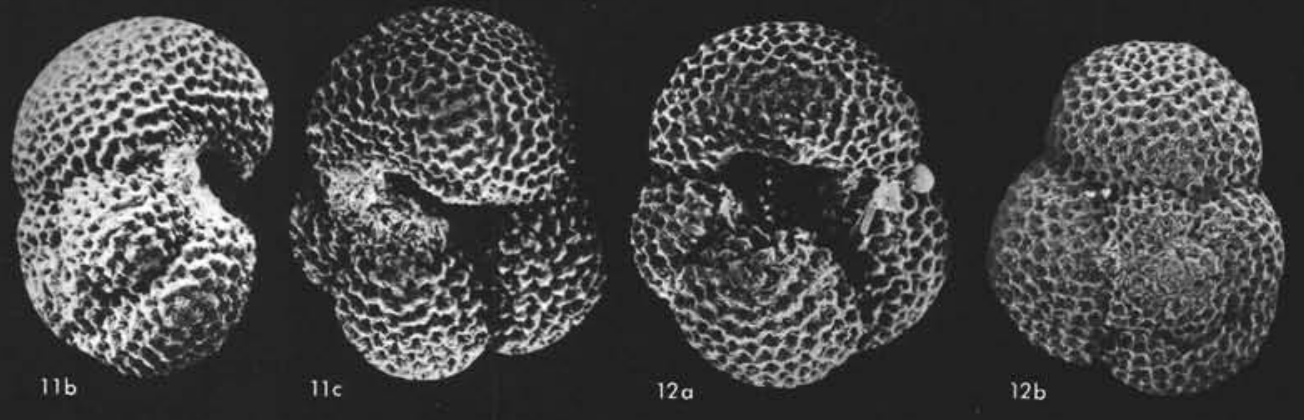


\section{PLATE 4}

Figures 1-3 Globorotalia wilesi Thompson, n. sp. Sample 435-12-1, 65-67 cm.

1a. Spiral side of holotype. $\times 125$.

$1 \mathrm{~b}$. Edge view of holotype. $\times 125$.

2a. Edge view of paratype. $\times 125$.

2 b. Umbilical side of paratype. $\times 125$. Sample 435-12-1, 65-67 cm.

3a. Edge view of paratype. $\times 100$.

3b. Umbilical view of paratype. $\times 100$.

Sample 435A-5-3, 18-20 cm.

Figure $4 \quad$ Globorotalia tosaensis Takayanagi and Saito.

Sample 435-4-2, 22-24 cm. $\times 130$.

Figure $5 \quad$ Globorotalia scitula (Brady).

Sample 435-1-5, 33-35 cm. $\times 75$.

Figure 6 Globorotalia crassaformis Galloway and Wissler. Sample 435A-6-1, 21-23 cm. $\times 125$.

Figure $7 \quad$ Globorotalia menardii (d'Orbigny). Sample 435-1-5, 33-35 cm. $\times 65$.

Figures 8, 9 Turborotalita quinqueloba (Natland). Sample 435-13,CC, 0-2 cm. $\times 175$.

Figures 10, 11 Pulleniatina obliquiloculata (Parker and Jones). Sample 435-4-2, 22-24 cm. $\times 90$. 

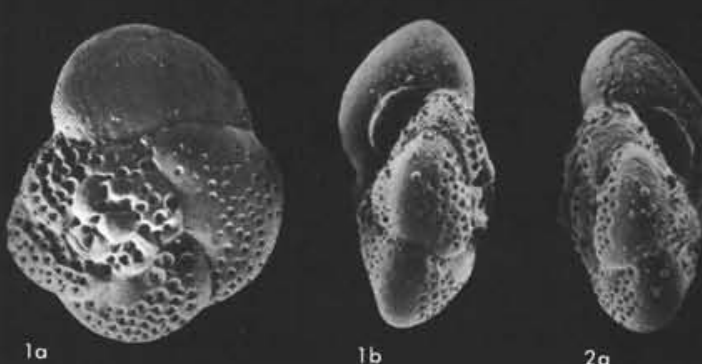
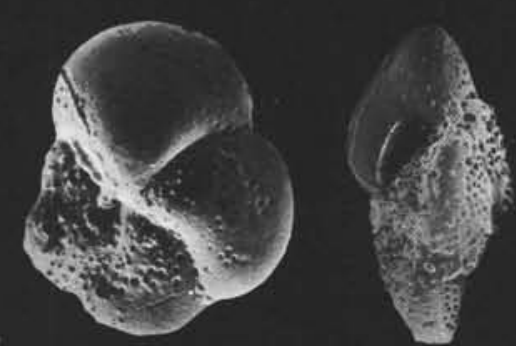

$2 \mathrm{~b}$

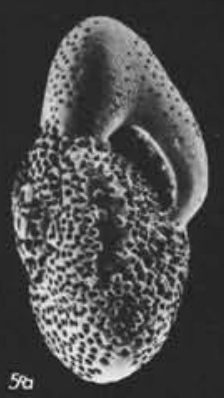

$3 a$

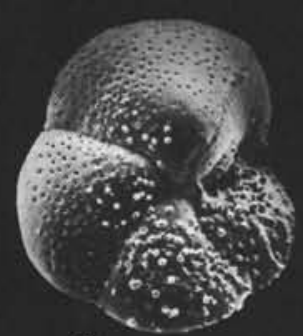

$3 b$
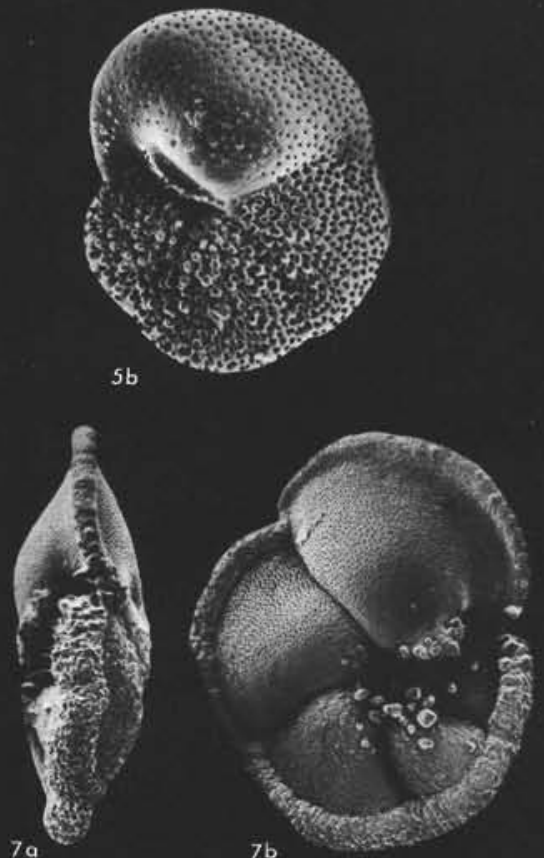

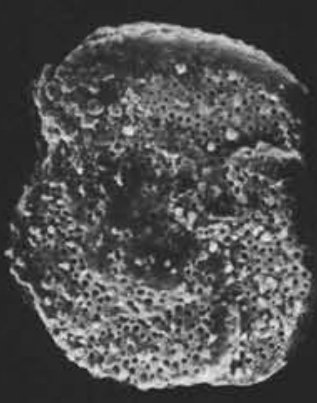

$6 c$
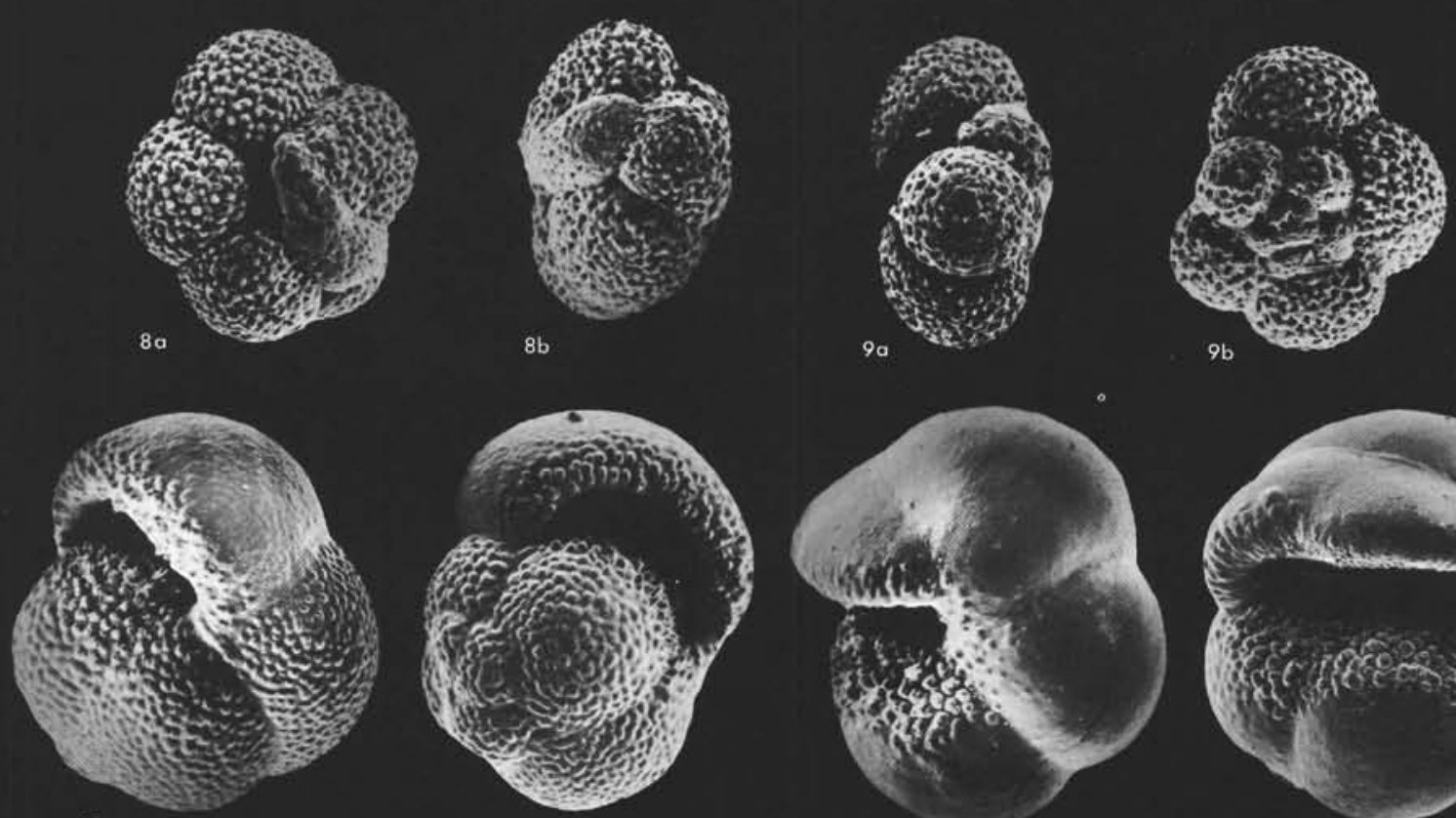

$10 \mathrm{~b}$
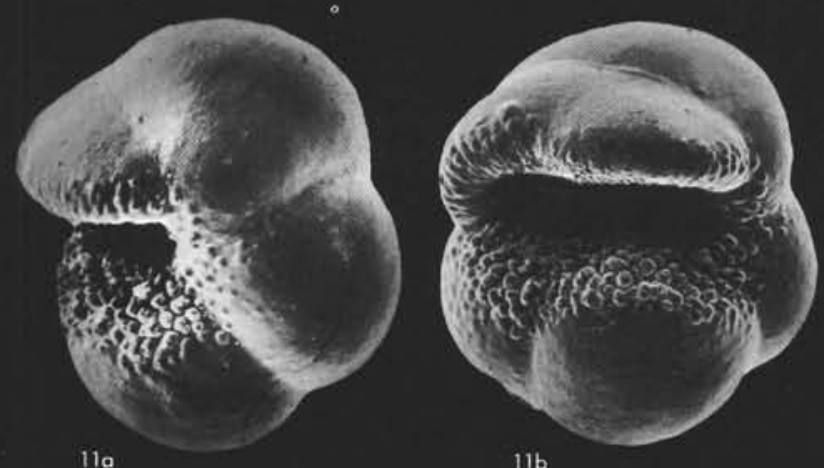


\section{PLATE 5}

Figures 1, 2, 4 Globorotalia inflata (d'Orbigny).

1 , 2. Sample 435-1-5, 33-35 cm. $\times 100$.

4. Sample 435-1-2, 33-35 cm. $\times 100$.

Figure 3 Globorotalia praeinflata Maiya, Saito, and Sato. Sample 435-13,CC, 0-2 cm. $\times 100$.

Figure $5 \quad$ Globorotalia puncticulata (Deshayes). Sample 435A-6-1, 21-23 cm. $\times 100$.

Figures 6-10 Globorotalia intermediate between G. puncticulata and $G$. suterae Catalano and Sprovieri, probably G. ikebei Maiya, Saito, and Sato.

Sample 435A-6-1, 21-23 cm. $\times 100$. 

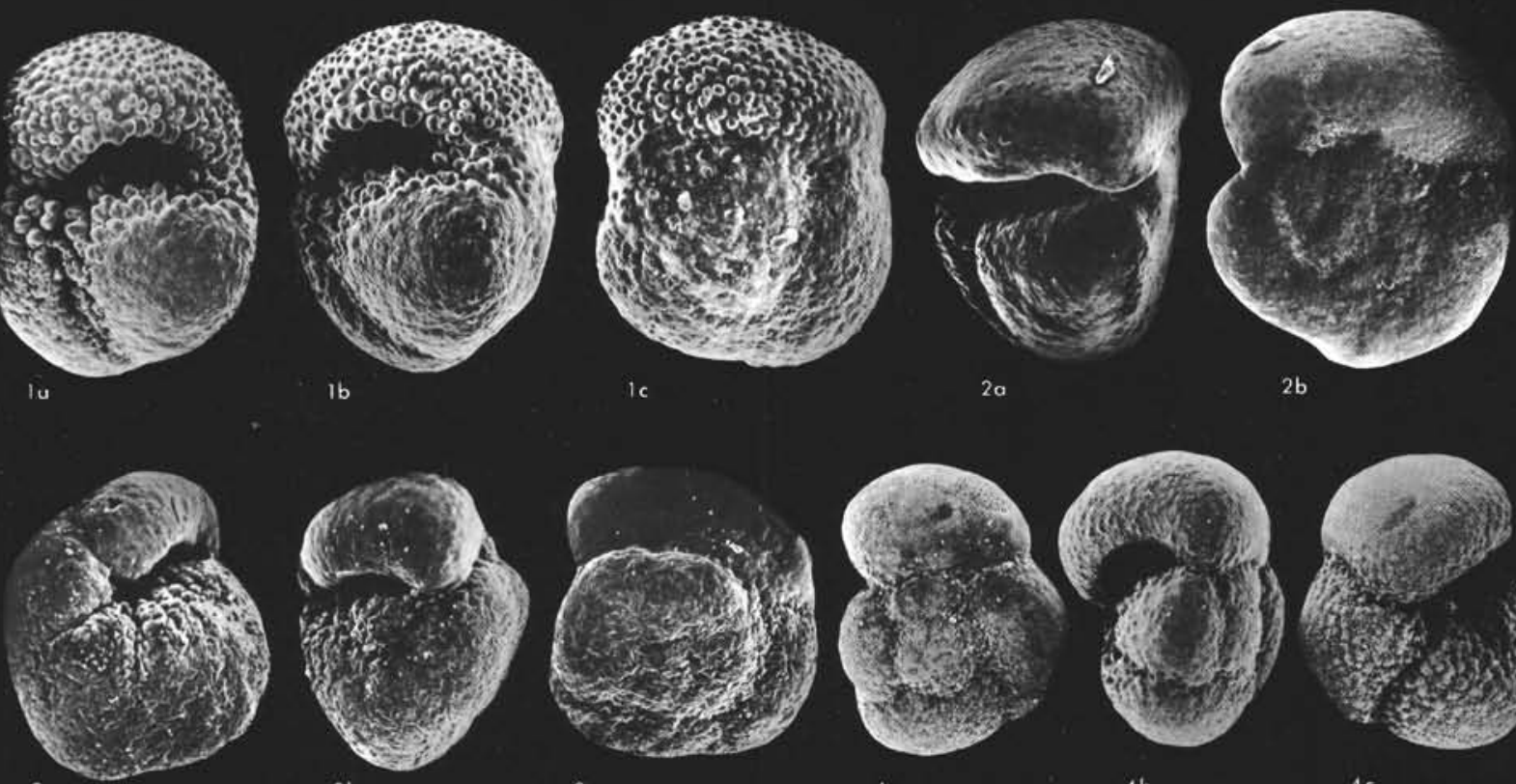

36

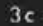

$4 a$
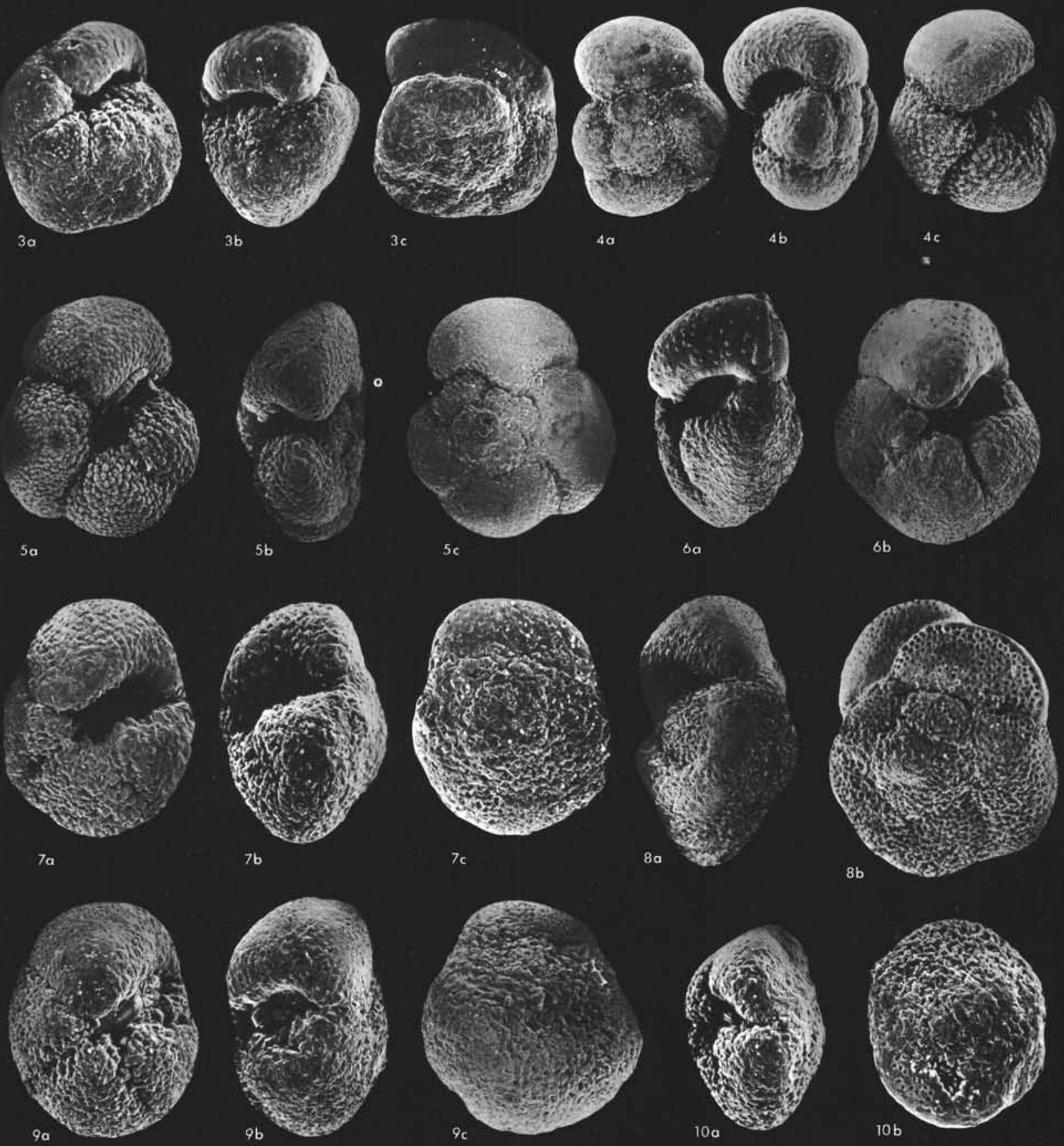


\section{PLATE 6}

Figure 1 Globorotalia puncticulata? (Deshayes).

Sample 435A-11-1, 30-32 cm. ×135.

1a. Spiral side.

1b. Edge view.

1c. Umbilical side.

Very poorly preserved.

Figure 2 Sphaeroidinellopsis sp.

Sample 435A-11-1, 30-32 cm. $\times 140$.

Apertural view. Very poorly preserved.

Figure 3 Globorotalia sp. cf. G. merotumida Blow and Ban-

ner.

Sample 434B-3,CC, 7-9 cm. $\times 120$.

3a. Spiral side.

3b. Edge view.

3c. Umbilical side.

Very poorly preserved.

Figure $4 \quad$ Eggerella bradyi (Cushman).

Sample 435-4-2, 22-24 cm. $\times 110$.

Equatorial view.

Figure 5 Sphaeroidina bulloides d'Orbigny.

Sample 435-4-2, 22-24 cm. $\times 150$.

Apertural view.

Figure $6 \quad$ Islandiella helenae Feyling-Hanssen and Buzas.

Sample 435-4-2, 22-24 cm. $\times 140$.

6a. Dorsal side.

6b. Edge view.

6c. Ventral side.

Figure $7 \quad$ Globocassidulina rossensis Kennett. Sample 435-4-2, 22-24 cm. $\times 150$.

Apertural view.

Figure $8 \quad$ Gyroidina soldanii d'Orbigny.

Sample 435-4-2, 22-24 cm. $\times 125$.

8 a. Umbilical view.

8b. Edge view.

8c. Spiral view.

Figure 9 Globobulimina ovata d'Orbigny.

Sample 435-12-1, 65-67 cm. $\times 65$.

Equatorial view. 
PLATE 6
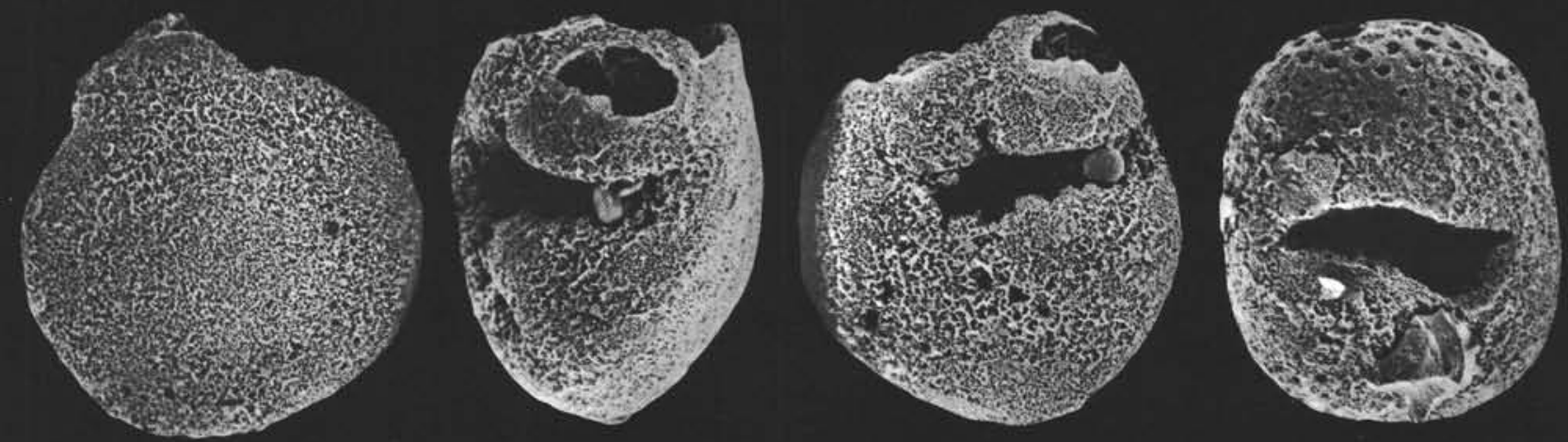

la

1b

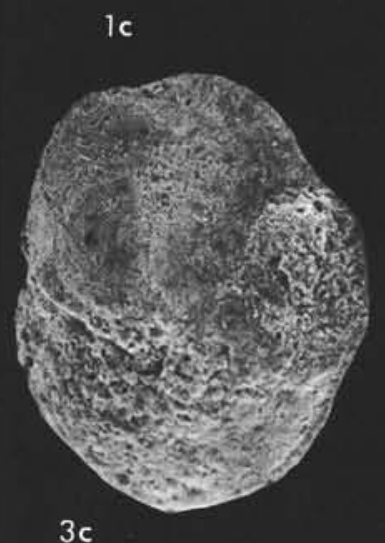

2

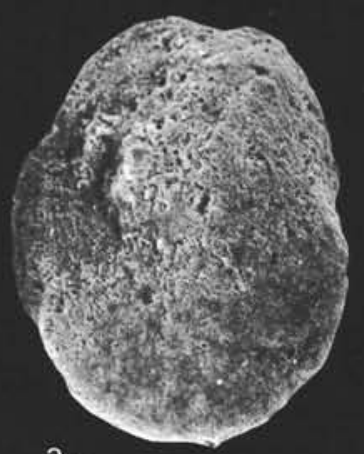

$3 a$

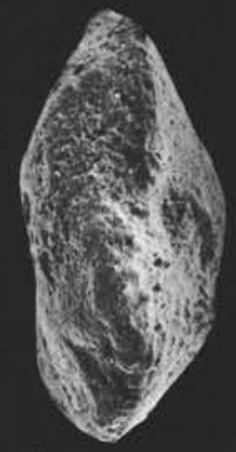

$3 b$
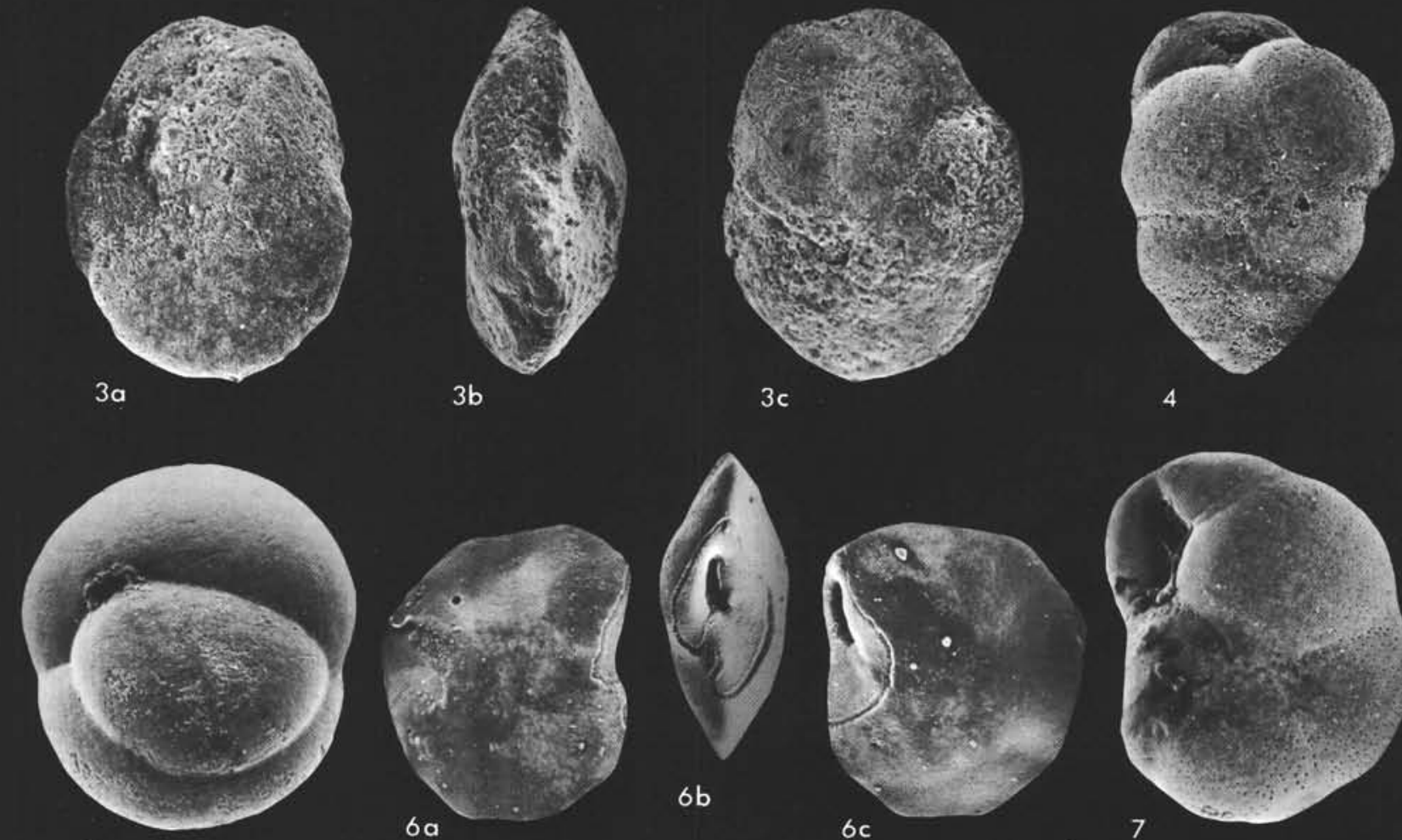

$6 b$

5
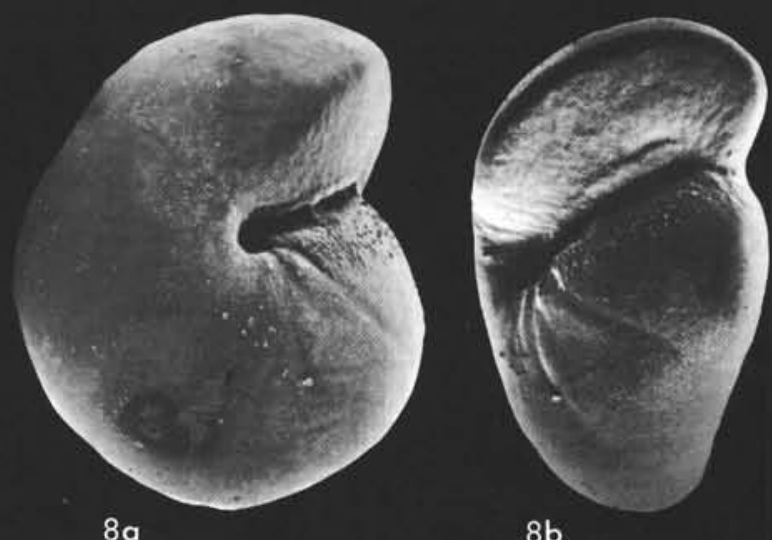

$8 b$

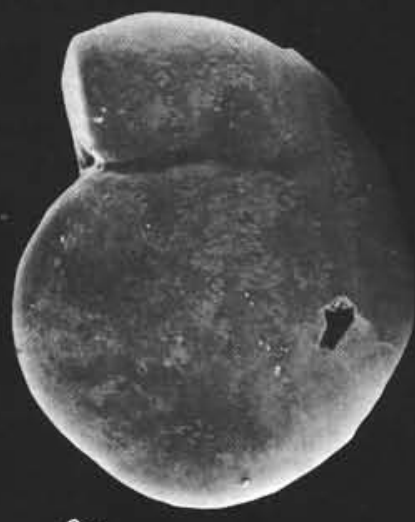

$8 c$
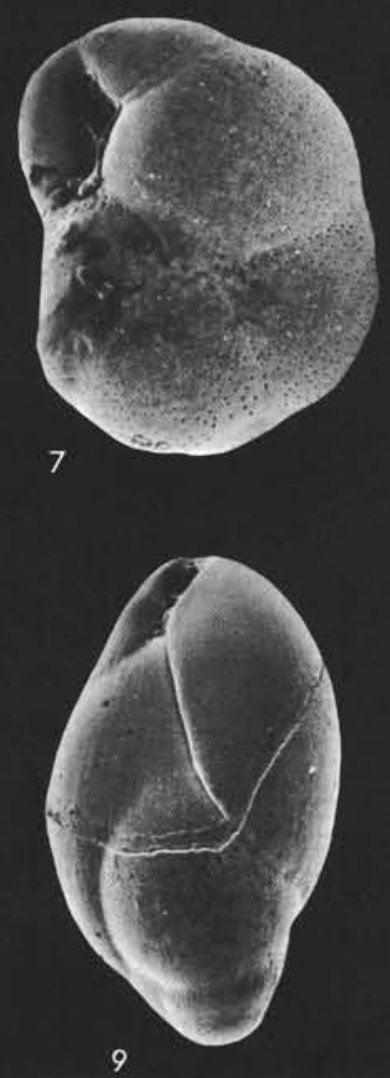
Figure $1 \quad$ Nonionella globosa Ishiwada. Sample 435-4-2, 22-24 cm. $\times 85$.

1a. Side view.

1b. Spiral view.

Figure 2 Nonionellina labradorica (Dawson).

Sample 435-1-2, 33-35 cm. $\times 60$.

2a. Side view.

2b. Umbilical view.

Figures 3, $6 \quad$ Elphidium batialis Saidova.

Sample 435-1-2, 33-35 cm.

3a. Side view. $\times 60$.

3b. Equatorial view. $\times 60$.

6. Umbilical canal system from another specimen. $\times 230$.

Figure $4 \quad$ Melonis pompilioides (Fichtel and Moll).

Sample 435A-5-3, 18-20 cm. $\times 100$

4 a. Side view.

4b. Equatorial view.

Figure 5 Melonis barleeanum (Williamson). Sample 435A-5-3, 18-20 cm. $\times 85$.

5a. Side view.

5 b. Equatorial view.

Figures 7, 8 Cibicides wuellerstorfi (Schwager).

Sample 435-1-2, 33-35 cm. $\times 45$.

7a. Umbilical view.

7b. Spiral view.

8. Side view of another specimen.

Figure 9 Pullenia bulloides (d'Orbigny).

Sample 435-1-2, 33-35 cm. $\times 100$

Side view.

Figure $10 \quad$ Saccammina sphaerica Sars.

Sample 435-1-2, 33-35 cm. $\times 80$.

Figures 11, 12 Hoeglundina elegans (d'Orbigny). Sample 435A-9-2, 37-39 cm. $\times 75$.

11. Umbilical view.

12a. Edge view.

12b. Spiral view of another specimen.

Figures 13, 15 Pyrgo murrhyina (Schwager).

Sample 435-4-2, 22-24 cm. $\times 75$.

$13 a, 15 a$. Ventral sides.

13b, 15b. Apertural view.

Figure $14 \quad$ Pyrgo sp.

Sample 435-1-2, 33-35 cm. $\times 50$

14a. Ventral view.

14b. Apertural view.. 


\section{PLATE 7}
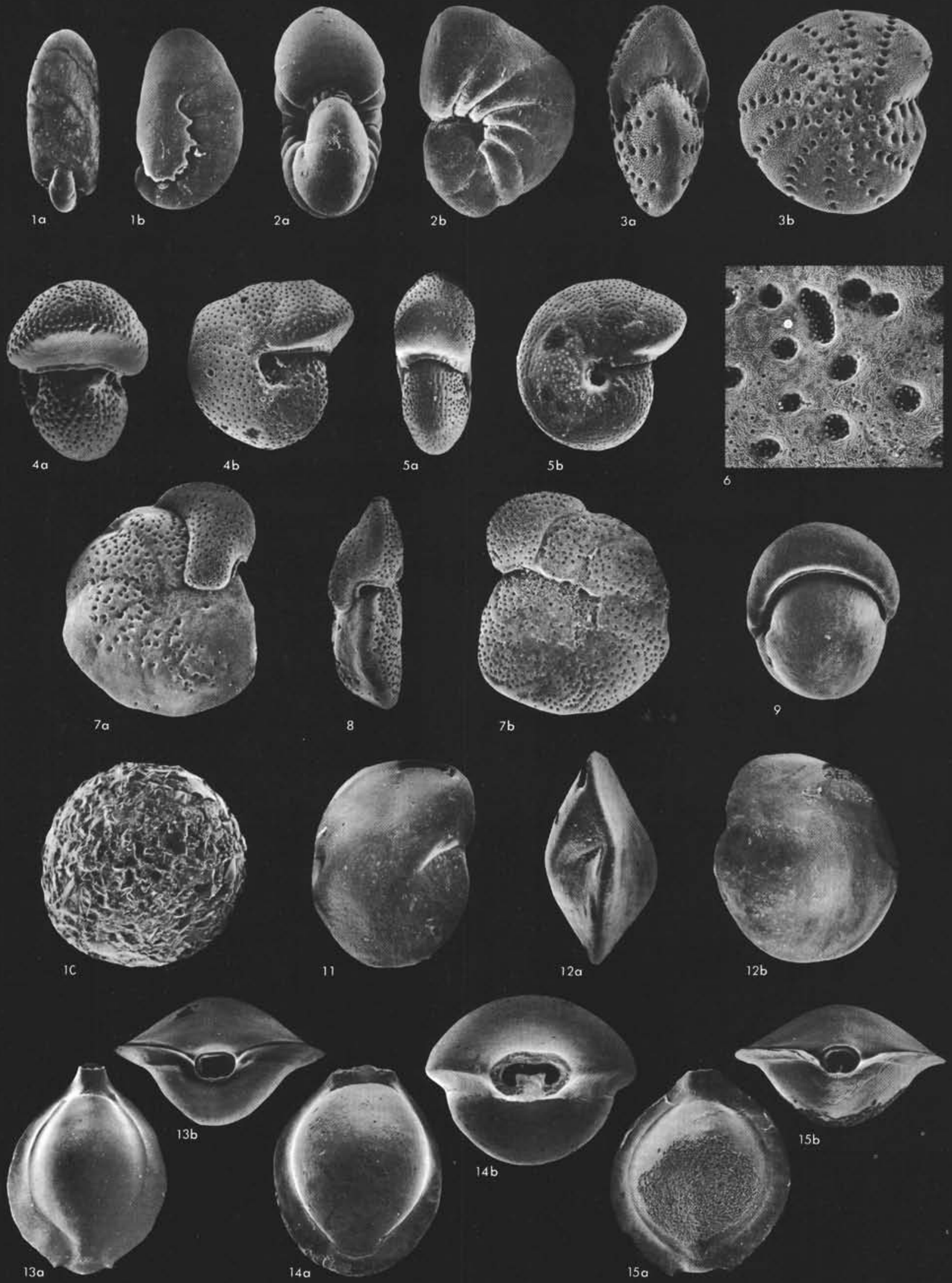


\section{PLATE 8}

Figures 1, 2 Plectofrondicularia advena (Cushman). Sample 435A-5-3, 18-20 cm. $\times 40$.

1, 2. Equatorial views.

Figure 3 Stilostomella bradyi (Cushman). Sample 435A-5-3, 18-20 cm. $\times 57$.

Figure 4 Stilostomella fistuca (Schwager). Sample 435A-5-3, 18-20 cm. $\times 50$.

Figure 5

Dentalina sp.

Sample 435A-5-3, 18-20 cm. $\times 58$.

Figure 6 Dentalina sp.

Sample 435-1-2, 33-35 cm. $\times 38$.

Figure 7 Siphonodosaria consobrina (d'Orbigny). Sample 435A-5-3, 18-20 cm. $\times 30$.

Figure $8 \quad$ Textularia sp.

Sample 435A-5-3, 18-20 cm. $\times 150$.

Figure 9 Martinotiella communis d'Orbigny. Sample 435A-6-2, 21-23 cm. $\times 35$.

Figure 10 Stainforthia loeblichi Feyling-Hanssen. Sample 435-1-2, 33-35 cm. $\times 78$.

Figure $11 \quad$ Uvigerina senticosa Cushman. Sample 435-1-2, 33-35 cm. $\times 56$.

Figure $12 \quad$ Uvigerina akitaensis Asano.

Sample 435-1-2, 33-35 cm. $\times 45$.

Figure $13 \quad$ Uvigerina hispida Schwager.

Sample 435-1-2, 33-35 cm. $\times 62$.

Figure $14 \quad$ Haplophragmoides? sp.

Sample 436-34-1, 43-45 cm. $\times 58$.

Figure $15 \quad$ Cyclammina cancellata Brady.

Sample 436-34-2, 43-45 cm. $\times 35$.

Figures 16, 17 Silicosigmoilina splendida Thompson, n. sp. Sample 436-9-1, 103-105 cm.

16. Test surface, $\times 1475$.

$17 \mathrm{a}$. Side view of holotype. $\times 138$.

$17 \mathrm{~b}$. Equatorial view of holotype. $\times 138$.

17c. Apertural view of holotype. $\times 138$.

$17 \mathrm{~d}$. Detail of aperture of holotype. $\times 675$. 
PLATE 8
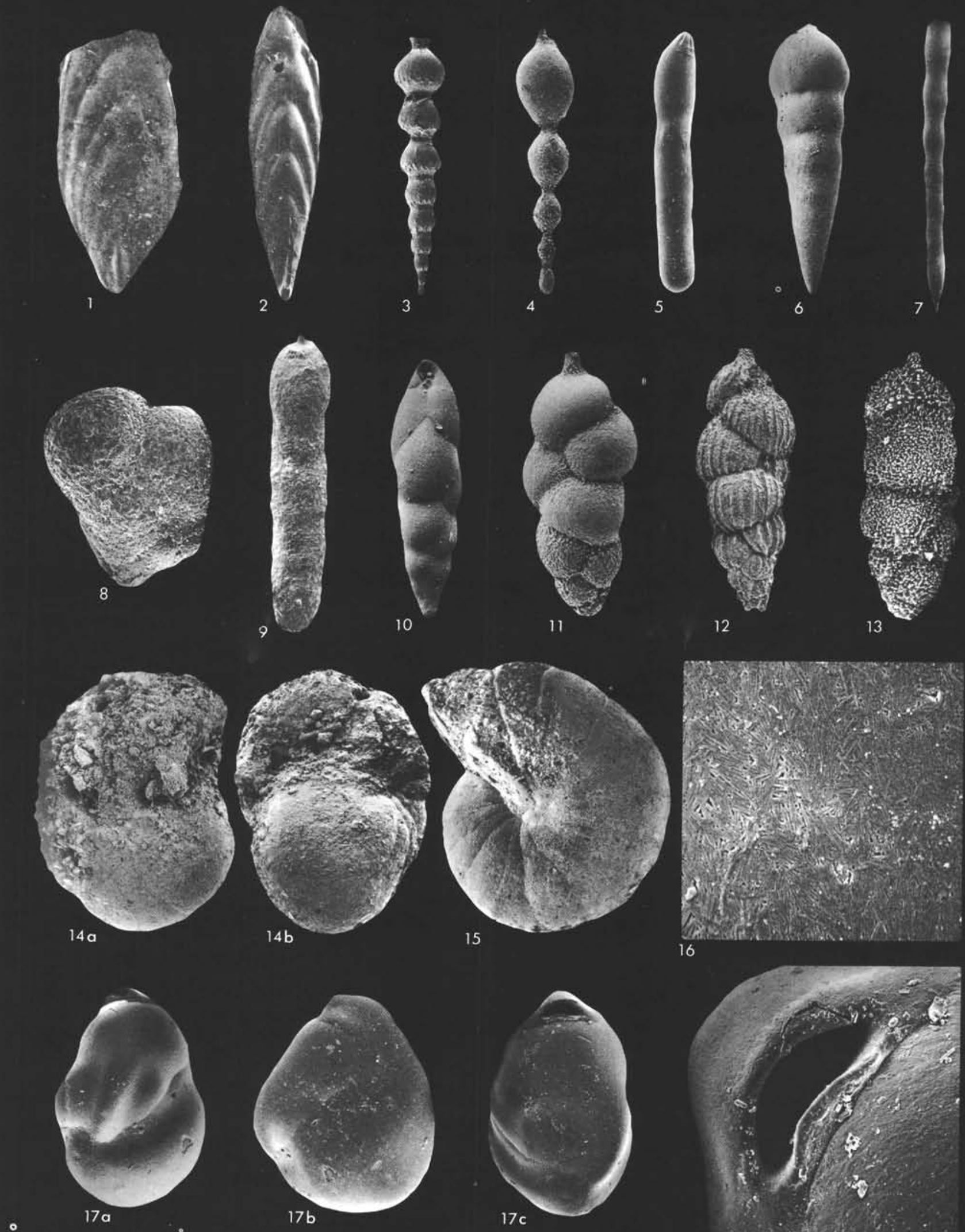


\section{PLATE 9}

Figures 1-5 Sample 436-39-6, 13-15 cm. $\times 250$.

External molds of juvenile globigerinids or globorotaliids inside manganese micronodules. Note how the shape of the foraminifer helps determine the shape of the nodule. Nucleation of the manganese must have been very rapid to prevent dissolution of these small specimens. 
PLATE 9

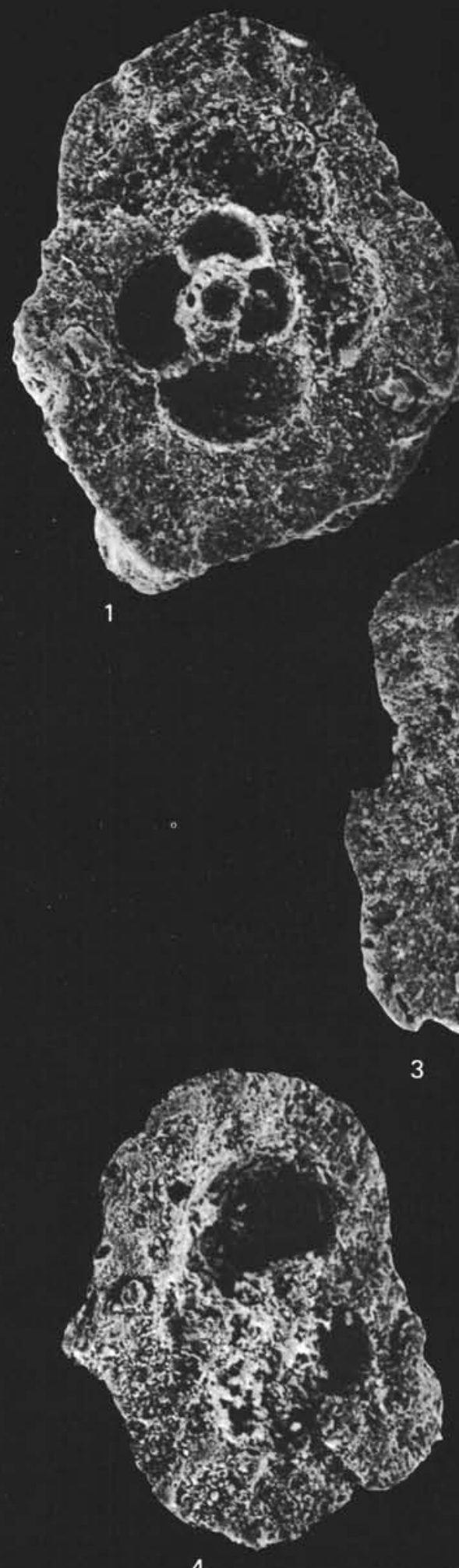

4

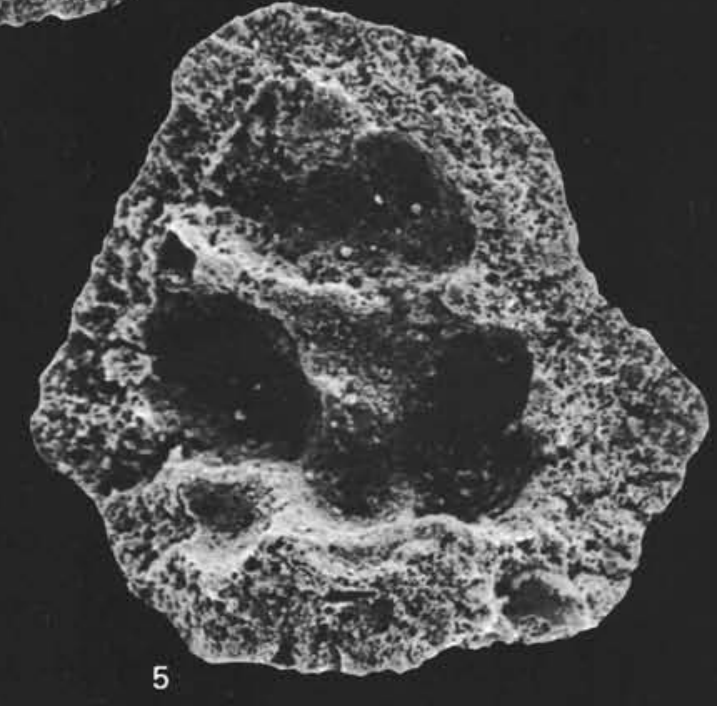

